\title{
Social movement NGOs and the comprehensiveness of conflict mineral disclosures: evidence from global companies
}

\author{
Muhammad Azizul Islam and Chris J. van Staden ${ }^{¥ 1}$ \\ \#Accountancy Discipline, University of Aberdeen Business School, UK \\ ${ }^{\sharp}$ Department of Accounting, Auckland University of Technology, New Zealand
}

\begin{abstract}
Conflict minerals refer to raw materials associated with conflicts and human rights violations in conflict zones around the world. Concern about the lack of transparency in the mineral supply chains of global corporations has led to increased stakeholder concern and pressure through protest action. In particular since 2009, numerous public-private collaborations, including collaborations with NGOs and industry-led initiatives, have sought greater transparency in companies' sourcing from conflict mineral zones. This has led to the enactment of the 'Dodd-Frank Act' in the US to regulate the disclosure of involvement in conflict minerals. This requirement suggests that corporate obligations now go beyond their own operations and that companies are held accountable for the actions of their suppliers with regards to their supply chains.
\end{abstract}

While the act requires minimum disclosure by companies, we hypothesise that companies' collaboration with social movement NGOs and activist protests against companies will influence the comprehensiveness of their conflict mineral disclosures. Our hypothesis is grounded in social movement theory and the theory of collaboration. We test our hypothesis by focusing on a sample of global electronic reliant companies from 20 countries. Consistent with our expectations, we find that collaboration with NGOs (as social movement organizations) and activist protest lead to more comprehensive, and therefore more transparent, disclosures. Our findings suggest that in the presence of activist protest, NGO collaboration with corporations has a higher impact on the comprehensiveness of conflict mineral disclosures. Furthermore, the marginal effects on disclosure are more strongly driven by NGO collaboration than activist protest. Our findings have practical and policy implications in that improved corporate transparency is the result of social movement actions via NGOs, i.e., regulation on its own may not result in comprehensive disclosures.

Key words: conflict mineral disclosures, Dodd Frank Act, NGO collaboration, activist protests, social movement theory, theory of collaboration, disclosure comprehensiveness

Citation: Islam, M. A. \& van Staden, C. J. (Forthcoming), Social movement NGOs and the comprehensiveness of conflict mineral disclosures: evidence from global companies, Accounting, Organization and Society

\footnotetext{
${ }^{1}$ Corresponding Author
} 


\section{Introduction}

Across different industries and countries, there is widespread stakeholder concern over human rights violations in the supply chains of multi-national corporations sourcing from overseas, including in the conflict zones of Africa. Electronic reliant industries attract more attention, as their supply chains often include conflict minerals (Lezhnev and Hellmuth, 2012). ${ }^{2}$ In particular, lack of transparency about the origin of many consumer products sold has fuelled opposition to economic globalization and to present accountability practices (Mansfield and Mutz, 2013; Bregman et al., 2015). There is pressure from stakeholders, including Non-governmental Organizations (NGOs), for more transparent supply chains (Chen and Slotnick, 2015). In particular since 2009, numerous public-private collaborations, including collaborations with NGOs and industry-led initiatives, have sought greater transparency from companies who are sourcing from conflict mineral zones (Reinecke and Ansari, 2016; Lezhnev and Hellmuth, 2012; New, 2010). At a broader level, NGO collaborations with corporations appear to have a significant impact on solving particular social or environmental problems, and research focussing on NGO-Corporation collaboration within the domain of the management and social science literature is growing (Austin, 2000; Rondinelli and London, 2003; Mandell, 1999). However, the collaborative role of NGOs with the aim to influence corporate human rights (social) transparency, and associated disclosures, remains under investigated (e.g., Deegan and Blomquist, 2006; O’Dwyer and Unerman, 2016; O'Sullivan and O'Dwyer, 2015).

Human rights violations in supply chains range from human trafficking, child and slave labour, to lack of transparency in supply chains (Grootaert and Patrinos, 1999; Psacharopoulos, 1997; Kolk and Van Tulder, 2002; Haltsonen et al., 2007; World Bank, 2009; UN, 2008; Moodie, 2014) and have caused broad community concern (see for example, Kolk and Van Tulder, 2002; Shelton and Wachter, 2005; UN Global Compact, 2011; Kettis, 2009; Verbruggen et al., 2011). Our investigation deals with a new regulatory dimension of corporate responsibility, the 'Dodd-Frank Act' and in particular section 1502 of this act, which requires US listed companies to file an annual conflict mineral report with the Securities Exchange Commission (SEC). This act suggests that the obligation of corporations goes beyond their own operations and they are held accountable for the actions of their

\footnotetext{
2 The term 'Conflict Minerals' refers to raw materials that come from a particular part of the world where conflict is occurring that affects the mining (in that mining conditions are inhuman and life threatening) and trading (in that returns are used to finance conflicts) of those materials.
} 
suppliers with regards to their supply chains. In this paper we are particularly interested to understand the influence of social movement actions on the comprehensiveness of corporate disclosures to the SEC in relation to conflict minerals. ${ }^{3}$ While we specifically examine the influence of NGO collaboration on the comprehensiveness of conflict mineral disclosures, we also investigate whether activist protests influence disclosure practice in this area and interact with NGO collaboration to influence conflict mineral disclosure practices. Prior research found that legitimacy threatening incidents (see for example, Patten, 1992; Milne and Patten, 2002; Coetzee and Van Staden, 2011), stakeholder concerns, including protests (e.g., Islam and Deegan, 2008; Deegan and Islam, 2014), and media pressures (Brown and Deegan, 1998; Aerts and Cormier, 2009), influence corporate responsiveness, including disclosure responsiveness. Our focus on NGO protest (Kneip, 2013; King, 2008) is in line with research that consider the relationship between broader stakeholder concerns and corporate disclosures. While prior social movement and organisational research have focussed on how NGOs influence companies through protest as well as collaboration (see for example, De Bakker et al., 2013, Kneip, 2013; King and Soule, 2007; King, 2008; Soule and King, 2006), NGOs' roles to improve corporate social transparency and disclosures have received little attention. Whether and how corporate transparency and disclosure practices is influenced by the interaction between NGO collaboration and activist protest remains the most neglected part of the research.

Since the enactment of the Act, debates over disclosure have ensued (Taylor, 2014). At the heart of the arguments is the question of what information matters to investors and what mechanism is best suited to ensure that the right 'mix' of information is provided at the least cost to the system (Taylor, 2014). However, this is a unique situation as this appears to be the first Act in the US history that marks a major shift in the SEC's traditional role as a market regulator of financially material information (Nelson, 2014). Despite criticism from industry representatives, section 1502 requires disclosure regardless of materiality to the shareholders (Nelson, 2014). The rise of socially responsible stakeholders (including NGOs) has resulted in a significant paradigm shift away from accounting only for financial information, to more transparency on issues of human rights and social responsibility (Nelson, 2014). This also gives researchers a platform to reinforce the application of socially driven theoretical frameworks in explaining corporate disclosures (see for example, Deegan

\footnotetext{
${ }^{3}$ In this paper we refer to NGOs as social movement organisations and therefore our focus is social movement NGOs working in the area of conflict minerals.
} 
and Blomquist, 2006; Cho et al., 2015; Cho and Patten, 2007; Cannizzaro and Weiner, 2015) rather than conventional market based or shareholder driven theoretical models (e.g., Dhaliwal et al., 2012).

Our study is motivated by the debate over the comprehensiveness and transparency of corporate disclosures. Even if a disclosure is mandated by law, management still has discretion on how comprehensively it will be addressed (see for example, De Villiers and Van Staden, 2011; Criado-Jiménez et al., 2008; Wallace and Naser, 1996). In the case of conflict mineral disclosures, the Act requires minimum mandatory disclosures in relation to conflict minerals. In relation to the comprehensiveness of the disclosures, the Act largely remains silent, which raises questions about the comprehensiveness of the resulting disclosures. We take the view that while the act requires minimum disclosure, NGO activities are influencing the comprehensiveness of corporate disclosure responses. We therefore expect (and find) variations in the disclosures between companies. We find that collaboration with NGOs (as social movement organizations) and activist protest lead to more comprehensive, and therefore more transparent, disclosures. We also find that the interaction between NGO collaboration and protest action has a significant effect on disclosure. Our findings suggest that both collaboration and protest influence disclosure, but, after taking into account the scale of the two influences, collaboration tends to be more important. Our findings therefore suggest that social movement actions (collaboration and protest) through NGOs, improve corporate transparency and accountability.

The paper provides a valuable contribution by using both social movement theory (King and Soule, 2007) and collaboration theory (Wood and Gray, 1991) to examine influences on conflict mineral disclosures. While prior accounting studies have examined social disclosures, they relied on legitimacy theory and stakeholder theory and tend to be mostly qualitative (see, reviews within Deegan, 2002; Deegan and Blomquist, 2006; De Villiers and Van Staden, 2006; Deegan, 2014). Consequently, prior studies produced case based descriptive results that are mostly not generalizable. Given the lack of sufficient explanatory power in stakeholder theory (Deegan and Blomquist, 2006; King, 2008), and the lack of specificity of legitimacy theory (O’Dwyer and Unerman, 2016) we use social movement theory and collaboration theory to develop expectations about the influence of protest and collaboration on the comprehensiveness of corporate conflict mineral disclosures. Based on the joint consideration of social movement theory and collaboration theory, our contribution to the literature is the notion that in an attempt to create social accountability, collaboration with NGOs (Rondinelli and London, 2003) occur as a response to stakeholder 
pressures or extra institutional forces such as 'protest' towards the companies, and such collaboration in turn influence corporate social transparency and disclosures.

Within the social science literature, prior research investigated social movements as non-market forces (e.g., Davis et al., 2008) or as collaborations contributing to influence state policy and corporate policy and procedures. Despite the significant roles of NGOs in creating corporate human rights accountability, there is a lack of studies within the accounting literature that investigate and explain the influence of NGOs on corporate human rights transparency and associated disclosure practices (Deegan and Blomquist, 2006; O'Dwyer and Unerman, 2016; O'Sullivan and O'Dwyer, 2015). We respond in particular to the call by O'Dwyer and Unerman (2016) for further research to investigate corporate reporting on human rights. We are motivated by the findings of O'Sullivan and O'Dwyer (2015) that the NGO movement evoked a progression in social responsibility reporting in the banking sector. Despite the more prevalent and ongoing NGO involvement in the electronic reliant sector, there is so far little academic attention to address corporate responsiveness in this sector.

Improved transparency regarding conflict minerals can play an important role in reducing human rights violations in supply chains. We use US listed companies since this is the only jurisdiction at the time of our study where conflict mineral disclosures are required. However, we do not present this as a US centred study and include companies from a number of other countries that are listed in the USA. We are of the opinion that our results could apply to any country that implement similar legislation, e.g., the UK Modern Slavery Act of 2015 and the EU Conflict Minerals regulation of 2017. In this regard we show that our results are generalizable across countries.

The paper is laid out as follows. In the next part conflict minerals and efforts to reveal and remove the impact are discussed, followed by a discussion of corporate accountability in the supply chain in conflict zones and the contribution to the accounting and disclosure research literature. The theoretical framework and hypotheses are then developed. This is followed by the research methods where the measures are discussed and motivated, followed by the results and the discussion and conclusions.

\section{Conflict minerals and efforts to reveal and remove the impacts}

The exploitation and trade of conflict minerals originated in the Democratic Republic of the Congo (DRC). The extreme violence and human rights violations in the DRC have resulted in a loss of more than 5.4 million lives since it was instigated in the late 1990's (Global Witness, 2011; Hogg, 2012). For years, rebels have illegally mined minerals and sold them to 
multinational companies (MNCs) to fund their war efforts in the DRC (Global Witness, 2011). It is mostly companies within the electronics reliant industries which activists and NGOs accuse of fuelling or financing armed groups in the DRC and activists have been campaigning to get companies to remove conflict minerals from their supply chains (Verbruggen et al., 2011). In producing countries, mineral-related legislation is rarely executed or enforced (BSR, 2010). This is because of massive human rights violations, corruption, insufficient political will and a lack of capacity and infrastructure as well as power imbalances (e.g., unequal negotiating capacities between communities, smaller producing nations and MNCs) in these countries while non-existent borders make illicit minerals flow easily (Moodie, 2014; BSR, 2010).

Generally, there is concern over irresponsible supply chain practices across industries ranging from the clothing industry, mining industry to the electronic reliant industries (AFLCIO, 2011; Haltsonen et al., 2007; Bachman, 2000; Spar, 1998; Wah, 1998; OneWorld US, 2006; Share, 2011; ILO, 2005; UN Global Compact, 2011; Carpenter, 2012; Amnesty International, 2015). Within the electronic reliant industries, there is even greater stakeholder concern over the use of conflict minerals from the DRC in particular. The United States Geological Survey (USGS, 2010) indicates that the DRC is the world's conflict mineral supplier with the greatest percentages of $3 \mathrm{~T}$ elements (tin, tantalum, tungsten). The four main conflict minerals are being mined in the DRC (the 3Ts and gold) and most of these minerals eventually present or wind up in electronic devices produced by the electronic based industries (USGS, 2010). Many electronic related companies are suspected of incorporating these elements directly and/or indirectly through their complex supply chains and it is a challenge for regulatory bodies and auditors to identify and control (Matthews, 2013).

There are various NGOs dedicated either entirely to the DRC or devoting a significant part of their work to end the use of conflict minerals. In relation to conflict minerals, NGOs working in the area includes Falling Whistles, Global Witness, Raise Hope for Congo, Free2Work, and Conflict Free Sourcing Initiatives. While one group of NGOs campaign and protest against irresponsible corporate behaviour, another group collaborate with companies to help eliminate irresponsible behaviour. For example, Raise Hope for Congo independently campaign against companies in order to end the use of conflict minerals. As a subdivision of the 'Enough' project, which aims to stop and prevent genocide, Raise Hope for Congo works with both Congolese and international organizations, like Amnesty International (Carpenter, 2012). It seeks to increase the prominence of the conflict in the media, offering individuals 
information and a number of possibilities to get involved. ${ }^{4}$ Knowledge of the conflict is on the rise in the public eye, causing pressure on policy makers and companies involved (Carpenter, 2012). On the other hand, an example of a NGO that collaborate with companies is Conflict Free Sourcing Initiatives (CFSI). CFSI is a multi-stakeholder initiative that collaborate with companies as monitor and/or inspector in an attempt to bring about change by helping companies to ensure transparency in (conflict mineral) supply chains and to enable the sourcing of conflict free minerals. ${ }^{5}$ The collaborations also focus on whether and to what extent concerned companies implement existing norms and laws (such as the DoddFrank Act) in relation to conflict minerals.

Over the last decade, due to the activism of social movement NGOs, the UN appointed panels of experts to investigate the exploitation of resources in the DRC (Leader, 2008), while the EU appointed representatives to review the trade of conflict minerals (Reese, 2010). In the US, social movements via NGOs and civil rights organizations supported the enactment of the Dodd-Frank Act (Dodd-Frank Wall Street Reform and Consumer Protection Act of 2010). This Act is one of the most visible initiatives coming out of campaigns by NGOs and social movements. On 16 July 2010, the Dodd-Frank Act was passed by Congress and on 22 August 2012, the SEC adopted Section 1502.

The provision on conflict minerals contained in the Section 1502 of the Act, obliges companies that trade on US stock exchanges and are implicated in their supply chains through the use of tin, tantalum, tungsten and gold, to apply due diligence and make recommended disclosures.

\section{Corporate accountability in the supply chain in conflict zones}

The Dodd Frank Act is the first act to deal with conflict minerals. The purpose of the Act is to further the humanitarian goal of ending violent conflict in the DRC and the adjoining region, which includes Angola, Burundi, the Central African Republic, the Republic of the Congo, Rwanda, South Sudan, Tanzania, Uganda and Zambia (Covered Countries). ${ }^{6}$ The Act requires disclosures to promote the exercise of due diligence on the source of conflict minerals in supply chains and to encourage companies to procure conflict minerals from sources that do not finance or benefit armed groups in the Covered Countries. The aim of the Act is not to ban the use of conflict minerals, but to create greater transparency and

\footnotetext{
${ }^{4}$ See http://www.raisehopeforcongo.org/content/about/about-the-campaign and Raise Hope for Congo (2010).

${ }^{5}$ See (http://www.conflictfreesourcing.org/about.

${ }^{6} \mathrm{See}$ http://www.sec.gov/News/Article/Detail/Article/1365171562058.
} 
responsible sourcing among companies. Section 1502 requires companies to file certain reports with the SEC to provide annual disclosures with regards to conflict minerals used in their products by 31 May 2014 for the first time (covering products manufactured starting 1 January 2013). The Section requires disclosures every 31 May thereafter that will cover products manufactured in the previous calendar year.

More specifically, under Section 1502, companies are required to determine if any of their manufactured products contain conflict minerals. Companies must perform a reasonable country of origin inquiry to determine whether minerals originated in the DRC or its neighbouring countries (OECD, 2011; Bowman, 2013, 2014; Ernst and Young, 2012) and can therefore be regarded as conflict minerals. Companies must disclose a description of the measures taken to exercise due diligence on the source and chain of supply - this should include a description of the due diligence process, including whether any recognized standards or guidance were used, and the facilities used to process minerals and the efforts undertaken to determine the mine or location of origin (SEC, 2012). If it can be established that the minerals do not originate from the DRC regions, the company is not required to file a conflict minerals report. However, if the minerals originate from the DRC regions or if the origin of the minerals is unclear, the company will be required to file a conflict minerals report, including an independent private sector audit (Ernst and Young, 2012). In the event that the origin is unclear, companies are allowed to classify the mineral as 'undeterminable' and describe the due diligence process used to determine the origin of the minerals. If a company files an inaccurate conflict minerals report, it could face financial penalties under the Securities Exchange Act (SEC, 2012). Furthermore, the language in the law imply that any company with raw material supply chains overseas may be subject to the disclosure regulations and the Act has not established a materiality threshold that would preclude the applicability of the reporting requirements. ${ }^{7}$

According to the SEC rule (section 1502), the due diligence process requires companies to identify, prevent, mitigate and account for how they address any adverse human rights impacts. The UN's 'Protect, Respect and Remedy' Framework for Business and Human Rights, indicates that 'the process should include assessing actual and potential human rights impacts, integrating and acting upon the findings, tracking responses, and communicating how impacts are addressed'(Ruggie, 2011, p.16). In contexts where there is a

\footnotetext{
${ }^{7}$ See the Federal Register (2010) on this link: https://www.sec.gov/rules/proposed/2010/34-63547fr.pdf, last viewed March 31, 2017.
} 
risk of contributing to conflict, risk-based due diligence is necessary to address potential and actual risks, and to mitigate the adverse impacts of activity and/or sourcing (OECD, 2011). The SEC has instructed companies to use a nationally or internationally recognized due diligence framework, such as the Guidance for Responsible Supply Chains from the Organization of Economic Co-operation and Development (OECD) (Hochfelder, 2014). Due diligence is very important because it is an on-going, proactive and reactive process through which companies can ensure that they respect human rights and do not contribute to conflict (OECD, 2013). The structure of the OECD's due diligence in the supply chain process is as follows OECD (2013):

- Establish strong company management systems

- Identify and assess risk in the supply chain

- Design and implement a strategy to respond to identified risks

- Carry out independent third-party audit of supply chain due diligence at identified points in the supply chain

- Report on supply chain due diligence

The SEC's suggestion to use the due diligence process is a qualitative and voluntary guideline and there will therefore be variations between companies adopting the due diligence process.

However, there is concern about the application of the Section and also claims that many companies have failed to do the minimum required by the Section (Amnesty International, 2015). De Villiers and Van Staden (2011, p.512) argue that managers choose to disclose varying volumes of both discretionary and mandatory disclosures, while Wallace and Naser (1996) find that there are cross-sectional variation in the comprehensiveness of mandatory information contained in corporate annual reports. Furthermore, the legal consequences of poor conflict minerals filings have yet to be tested. Similar to other filing requirements, the SEC can sanction companies that file false and misleading conflict mineral reports or fail to file a report when one is required. The SEC has the power to delist a company from the stock exchange, but this is used extremely rarely and only against repeat offenders (Amnesty International, 2015).

From this perspective, we do not know much about the consequence of failing to meet the Section 1502 requirements or how comprehensively companies choose to disclose on conflict minerals. Investigating the role of NGOs in influencing more comprehensive conflict mineral disclosures is therefore important. 


\section{Prior research and contributions of this study}

Prior research has examined how market or shareholder expectations (Ness and Mirza, 1991; Dhaliwal et al., 2012), regulators (Frost, 2007), media (Deegan et al., 2002; Islam and Deegan, 2010), NGOs (Deegan and Blomquist, 2006; O'Sullivan and O'Dwyer, 2015), and Intergovernmental Organizations (IGOs) (Islam and McPhail, 2011) influence different types of corporate social and environmental disclosures. We extend the prior research by looking at whether and how NGOs influence the comprehensiveness of a specific type of corporate disclosure, i.e., supply chain disclosures in relation to the use of conflict minerals, or simply conflict mineral disclosures.

Prior accounting literature that looked at supply chains mainly investigated management accounting practices within the supply chain (Frances and Garnsey, 1996; Langfield-Smith and Smith, 2003; Seal et al., 2004; Free, 2008; Bhimani and Ncube, 2006; Gosman and Kohlbeck, 2009; Neu et al., 2014). Prior management accounting research in particular focussed on trust and buyer-supplier relationships while pursuing economic gains (see for example, Free, 2008), cost-benefit analysis of external supply alliances (see for example, Bhimani and Ncube, 2006), coordination and control in low-price production chains (see for example, Neu et al., 2014) and how buyer power in the retail market affects suppliers' profitability (see for example, Gosman and Kohlbeck, 2009). Spence and Rinaldi (2014) show that retailers are effective in shaping the governance of supply chains. In other words, sustainability governance and control is found to transcend the corporate boundaries of MNC supply chains and extend to indirect governance of suppliers. Islam and Deegan (2010), by focusing on the social disclosures of two MNCs, provide an understanding of social disclosures by MNCs in relation to their supply chains. Both financial accounting and the voluntary disclosure literature have paid little attention to the supply chain. There is widespread global attention on the disclosures, transparency and accountability in supply chains and some stakeholders have put pressure on companies to be visible and transparent on the working conditions, including human trafficking, in their supply chains. Despite this, research investigating whether and how companies disclose human rights performance and associated transparency measures in the supply chain is scant. The limited research is also acknowledged by an insightful review of the literature by O'Dwyer and Unerman (2016, p. 38): '...numerous issues central to social sustainability, such as reporting on human rights, supply chain abuses, and fair trade, have received limited attention in AOS'. 
The rise of socially responsible stakeholders and a major shift in the regulator's (the SEC) traditional role as a regulator of financially material information to non-financial (social and environmental) information appears to question market based arguments for social and environmental reporting and performance. Accounting research, using non-market based arguments, investigating whether and how external actors or secondary stakeholders to the organizations influence organizational social and environmental disclosure practices is growing (see for example, Patten, 2002; Deegan and Blomquist, 2006; Cooper and Owen, 2007; Islam and Deegan, 2008, 2010; Deegan and Islam, 2014). Given the lack of a direct voice in corporate decision making, external or secondary stakeholders must find other means such as protest and/or collaboration to influence corporate change, including disclosure related change. However, there is limited research that investigates whether NGOs influence corporate disclosure practices. Within the sociology literature, the role of NGOs and social movement organizations in influencing organizational operating practices (including organizational policy, procedures and even actions) is well researched (see for example, Davis et al., 2008). While the NGO movement is studied in the sociology literature, disclosure is not considered as an issue of this research.

Accounting research on social responsibility reporting is dominated by legitimacy theory and stakeholder theory, focussing mainly on the need for legitimacy and potential insights for policy implications (Deegan, 2014; Unerman and Chapman, 2014). We argue that NGOs' influence on disclosure regulation and their subsequent monitoring of corporate actions cannot be explained by legitimacy theory, following the criticism by O'Dwyer and Unerman (2016) that everything can be explained by legitimacy theory and therefore it does not provide enough insight into corporate accountability and transparency. Furthermore, NGOs as actors of corporate legitimation have so far not been well explained by researchers who used legitimacy theory (with the possible exception of Deegan and Blomquist, 2006). As NGOs can be considered as secondary stakeholders of corporations, stakeholder theory can be utilized to analyse NGOs' influence on corporate disclosure practices (Deegan and Blomquist, 2006). However, critics argue that stakeholder theory (in particular with regards to social movements) is not sufficiently explanatory and is not able to identify causal linkages whereby secondary stakeholders, such as social movement organisations (i.e., NGOs), exert pressure and influence change (King, 2008).

Prior research within accounting and disclosure have looked at the role of NGOs to understand their influence on corporate social and environmental performance and associated disclosure practices (see for example, Deegan and Blomquist, 2006 and Deegan and Islam, 
2014). Deegan and Blomquist showed how the WWF Australia was able to influence the reporting requirements incorporated within the Australian mineral industry's environmental performance code. The study also showed that senior executives of the mineral industry responded to the WWF's sanctioning of the performance code to maintain legitimacy. Deegan and Islam (2014) find that NGOs have a role to create corporate accountability and disclosure practices. They show that NGOs use the news media to create accountability practices in a developing nation connected with international trade. O'Sullivan and O'Dwyer (2015) examined the roles of social movement NGOs to create social accountability surrounding the Equator Principles within the banking industry. They found NGO movements focusing on socially responsible finance triggered changes in the social accountability and reporting behaviour in the banking industry. There is research focusing on NGOs' accountability to meet their social objectives (see for example, O'Dwyer and Unerman, 2008; Martinez and Cooper, 2017), without necessarily focusing on corporations. Some of this research found that NGOs as social movement organisations have been disarticulated due to economic influences and 'NGOization' (Martinez and Cooper, 2017). We find that prior research that investigated the role of NGOs to influence particular corporate disclosures, did not focus on NGOs and their collaborations with companies in relation to the creation of corporate transparency within global supply chains. While the organisational literature considers how NGOs influence companies through protest and collaboration (i.e., De Bakker et al., 2013; King and Soule, 2007; King, 2008; Soule and King, 2006), whether and how the interaction between NGO collaboration and activist protest create corporate social transparency and accountability has not received attention in this literature.

In fact there is not much research in accounting that investigate NGOs' role in influencing corporate disclosures (see only, Deegan and Blomquist, 2006; Deegan and Islam, 2014 and Tilt, 1994), and this consists of case studies and did not attempt to generalise the influence of NGOs on particular corporate disclosures. There is also a complete lack of hypothesis driven empirical studies as acknowledged by Deegan and Blomquist (2006) that explores the influence of NGOs on corporate disclosures. More specifically, given the lack of explanatory power in stakeholder theory and legitimacy theory, and based on social movement theory, we develop hypotheses driven conceptual arguments about the influence of social movements, being (extra-) institutional forces (such as NGO protest, boycott or collaboration) on corporate disclosure behaviour. 
We make the following contributions to the literature: first we observe that external forces such as protest and collaboration (by NGOs as agents of social movement organizations) influence corporate disclosure practices, in particular the comprehensiveness of conflict mineral disclosure practices. In other words, this study contributes to the literature by empirically showing how NGO collaborations with companies and activist protest influence particular corporate disclosures. These NGO activities are rarely examined in the disclosure literature. Second, while prior research sees the issue of the environment and working conditions as central to the analysis of the roles of NGOs, we investigate the role of NGOs in influencing the comprehensiveness of disclosure and transparency in relation to human rights and the elimination of conflict minerals from supply chains. Third, NGOs' role in one industry is different from their roles in other industries. While prior research looked at the roles of NGOs in influencing company disclosures and accountability within the mineral industry (Deegan and Blomquist, 2006), the clothing and retail industry (Deegan and Islam, 2014) and the banking industry (O'Sullivan and O'Dwyer, 2015), we focus on disclosure practices within the electronic reliant industries. Companies in this industry face a major social problem, i.e., conflict minerals in their supply chains. The regulation requiring disclosure to the SEC offers a unique opportunity to investigate the influence of NGOs in these circumstances. Fourth, no-one so far looked at NGOs that collaborate with companies in order to improve transparency and accountability and the associated disclosure practices in relation to supply chains. Fifth and most importantly, this study uses social movement theory and the concept of collaboration to explain the notion of influence by NGOs which is different from the notion of influence explained in other studies. NGOs, via their activism (protests, campaigns and/or social movements), influenced the regulatory agency (i.e., the US SEC) to incorporate minimum disclosure requirements/regulations (for example, section 1502 of the Dodd Frank Act). Activist protest also influenced corporate change, encouraging corporates to collaborate with NGOs. NGOs formed collaborations with companies either to monitor or to implement the regulations and the disclosure requirements. We expect variation in the comprehensiveness of corporate disclosures depending on the level of NGO collaboration and activist protest, and the interactions between these.

\section{NGOs as social movement actors and the corporate response: a theoretical}

\section{framework and hypotheses}

We use social movement theory and the theory of collaboration to explore factors that influence the comprehensiveness of corporate disclosures in relation to conflict minerals. The 
theoretical framework in particular leads to hypotheses in relation to how institutional forces such as NGOs (through their collaboration and/or protest) influence the comprehensiveness of conflict mineral disclosures by global electronic reliant companies listed on US stock exchanges. Literature on social movement theory has been used by sociologists to understand organizational behaviour. Based on a review, Davis et al. (2008) argue that social movement theory has only recently spread into mainstream organizational studies. The theory can not only go beyond conventional explanations to reveal new insights, but can also open up new areas of inquiry (Davis et al., 2008). While earlier research by social movement scholars has focused almost exclusively on outcomes in the political domain, Davis et al. (2008) have emphasized the importance of looking at additional types of outcomes by giving attention to social movements that target companies and other business organizations. Given the central role that business organizations play in contemporary society, it is curious that both social movement scholars and accounting scholars have not yet considered the influence of social movements on disclosure transparency.

In the literature, the construct of social movement is found in the early work by Davies (1962), Gurr (1970), Toch (1965), Oberschall (1973), Tilly (1978) and Jenkins, (1983). Early social movement literature concentrated on causes (for example, Davies, 1962) and motivations (see for example, Toch, 1965) behind the social movements. Things have changed over the last two decades and social movements are now regarded as a cause for organizational change (see Davis et al., 2008; Soule, 2012). An important focus of social movement research has been the investigation of the modernisation of collective actions by Tilly (1978). Based on Tilly (1978), social movement theory comes from a central idea that social movement organizations, including NGOs, develop from their responsive actions to long term pre-emptive actions for the purpose of social development, or to create change to a way of life. The theory posits that social movement organizations can impact policy decisions at the state, local, national (Soule et al., 1999; Soule and King, 2006) and international levels. Social movements thus target existing systems of authority, such as the state, educational institutions and companies (King and Soule, 2007). Davis et al. (2008) argue that social movement research should be extended from the investigation of movements that are state centred to movements that are corporate-centred, but at the same time they believe that the research must explicitly take into account various kinds of institutional and extra-institutional activities (protest, boycott and collaboration) that play important roles in constraining and facilitating the influence of social movements on organizations and markets. The theory highlights the strength of supportive social movement organizations through their capacity to 
mobilise forces such as protest, lobbying and collaboration to influence policymakers (Soule and King, 2006) as well as the actors in the organization on which policy is imposed.

Social movements tend to challenge dominant institutions (states, corporations, or international bodies) and institutional arrangements (such as regulations, corporate codes of conduct, or other global and institutional norms and principles) (O'Sullivan and O'Dwyer, 2015). Social movement theory suggests that movements with a greater organizational capacity will be more effective than those lacking a strong organizational infrastructure (Soule and King, 2006). In her study, Soule (2009) provides some interesting cases of the implications of social movement organizations. She describes US activist attempts in the 1970s and 1980s to reinforce state regulation in the tuna fishing industry in an effort to decrease the number of dolphin deaths associated with the use of purse-seine nets. In another study, Soule (2012) argues that there has been a rise of private regulatory agencies (including NGOs) that certify corporate conduct and supply chains. She explains, for example, that the Forest Stewardship Council, the Marine Stewardship Council and Social Accountability International have all formed in recent years as private regulatory agencies which are mostly NGOs designated to monitor and certify products and supply chains.

O'Sullivan and O'Dwyer (2015) provide an understanding of how NGO movements fuelled an evolution in the social accountability and reporting in the banking sector. They argue that when new issues arise (i.e., the SEC's conflict mineral disclosure rules), actors such as NGOs may use their powerful field positions to create change in accountability. As O'Sullivan and O'Dwyer, (2015, p.47) argue:

'.....when mature field disruption or uncertainty arises because of a new issue of concern arising from outside the mature field - in our case, the issue of socially accountable finance advocated by an external NGO movement - these central actors use their powerful field positions to address the issue by instigating change that meets the conditions of the mature field'.

As companies shift their operations and/or sourcing of materials overseas, NGOs' roles as social movement organizations extend across national boundaries. Davis et al. (2008) argue that in an increasingly global economy, social movements are growing more transnational. NGOs, through their activities and changed strategies, create concern over human rights violations at companies' foreign operations. In response to this, more and more companies are changing their behaviour, this notion is ingrained in social movement theory. Davis et al. (2008) argue that social movements' approach to changing corporate behaviour range from sabotage to collaboration. Social movements address large-scale social problems 
in two primary ways. First, activists can influence corporate operating practices via protests and/or boycotts and second, NGOs can directly engage in collaboration to influence corporate activities and accountability practices. Put simply, NGOs influence companies through protest campaigns as well as collaborative partnership (De Bakker et al., 2013). In this regard, Davis et al. (2008) found that some organizations learn to tolerate and even work or collaborate with social movements that initially appeared to threaten their interests. They observe that important engagements between organizations and social movements are occurring in transnational contexts around the issues of global economic development, environmental protection and sustainability and even the dark side of transnational dynamics such as terrorism and struggles for social justice and equity. While the notion of protest by social movement organisations has been studied (see for example, King, 2008; King and Soule, 2007), the notion of social movement collaboration with corporations is relatively less studied.

We complement social movement theory with the theory of collaboration. According to Wood and Gray (1991) "collaboration occurs when a group of autonomous stakeholders of a problem domain engage in an interactive process, using shared rules, norms and structures, to act or decide on issues related to that domain" (p. 146). The key elements of the concept of collaboration deserves explanation. In the collaboration process, multiple stakeholders agree on what the problem is, and that the problem is important enough to work with others to find a solution (Gray, 1996). Stakeholders retain their independent decision making powers in achieving shared values/rules within the collaborative alliance. However, participating stakeholders must explicitly agree on the shared values or rules or structures that will govern their interactive process (Wood and Gray, 1991; Gray, 1996). In the final stage of the collaboration process, collaborators expect to see the implementation of the chosen course of action, requiring support and structure, including monitoring/auditing for compliance (Gray, 1996). NGOs and their collaborations with companies appear to influence the transparency and the openness of organizational actions. Collaboration is considered to exist as long as the stakeholders engage in a process intended to result in action or decisions (Wood and Gray, 1991). Interestingly, in a range of social environments, collaboration and organisational engagement in collaboration may occur as a response to stakeholder pressure and extrainstitutional forces such as 'protest'. Through protest or boycott, activist social movement organisations have an important extra-institutional influence in creating corporate responsiveness (King and Soule, 2007). Protest as an extra-institutional tactic of activists appeals to third parties by broadcasting grievances publicly (King, 2008). One of the 
common outcomes suggested is collaboration as a vehicle for social change. However, it is interesting to know why a company responds to the expectations of its collaborators. One of the important motivations for a company to respond to collaborators is a desire to maintain and enhance legitimacy (i.e., companies' collaboration with social movements have legitimating effects).

It is our expectation that social movement forces (such as protest) influence companies to collaborate with NGOs and that this collaboration will have legitimating effects. Furthermore we expect that companies will respond to the participation of NGOs in their transparency process in order to maintain their legitimacy. Prior social movement literature suggests that social movement organizations not only collaborate with protest groups in order to strengthen their movement (Wang and Soule, 2012), but also collaborate with companies to increase the influence of the social movement on enhanced corporate transparency and legitimacy (Soule, 2012). Soule (2012) has provided an interesting example of Coca Cola that has been criticized for its use of water in developing nations, especially in India. In recent years, Coca Cola has sought advice from several NGOs, including the World Wildlife Fund, and has entered into partnerships and collaborations in an effort to respond to the criticisms and protests by changing its practices.

Our expectation is also derived from the social movement literature that suggests that companies' collaborations with NGOs can help them overcome these challenges.

Collaborations can help companies and NGOs make sense of each other and channel institutional knowledge from the NGOs to the companies. Furthermore, the NGOs' standing in civil society may confer social legitimacy to companies (Oetzel and Doh, 2009). Collaboration with NGOs is therefore important if companies seek to maintain legitimacy in complex and diverse institutional environments (Kostova and Zaheer, 1999). Similarly we argue that NGOs in a particular context (i.e., in the context of conflict minerals), is a vital actor whose collaboration with concerned companies provide a greater level of legitimacy in the global setting. The essence of existing collaboration theory and research presents some ideas, but no firm conclusions, as to whether legitimation is the motivation for companies to collaborate on corporate transparency with stakeholders. The fundamental issue is to enhance legitimacy in the eyes of stakeholders who represent the broader community. And hence social movement organizations, such as NGOs, can become collaborating stakeholders that aim to bring change to society and represent broader community expectations.

In summary, social movement theory suggests that NGOs can be agents of change in organizational fields, by offering new solutions to collective problems (King and Soule, 
2007; Greenwood et al., 2002), creating change in the world of companies and business via the use of a tactical repertoire designed to complement their status as outsiders to those companies (Soule et al., 1999), or presenting themselves as alternative democratic voices (King and Soule, 2007). The concept of collaboration therefore suggests that companies or organizations engage in collaboration with NGOs to solve their problems, create change, enhance transparency and maintain legitimacy.

In the context of global supply chains, there are several human rights problems (child labour, human trafficking, slave and forced labour, etc.) to be resolved (through collaboration) in general. Historically NGOs have a significant role in creating change within the global supply chains. For example, within the clothing industry, NGO social movements in the USA led by the Asian American Free Labor Institute (AAFLI) have shaken the whole industry and global actors through their anti-child labour campaigns and protests. Within the supply chain of the electronic reliant industries, NGOs have a role to create an environment to influence the comprehensiveness (and thereby the transparency) of disclosures in relation to conflict minerals. Based on the above discussion of social movement theory and the concept of collaboration, we propose the following hypothesis:

$\mathrm{H}_{1}$ : Collaboration with NGOs will result in more comprehensive corporate conflict mineral disclosures.

There are different categories of NGO-corporation collaboration to pursue different social and environmental goals (Austin, 2000; Arenas et al., 2009; Rondinelli and London, 2003; Kolk and Lenfant, 2012; Mandell, 1999). Based on the degree of interaction and level of engagement, there can be different levels or types of collaboration, i.e., arm's length relationships, interactive collaborations, intensive alliances and transformational collaborations (Rondinelli and London, 2003; Kolk and Lenfant, 2012). In the collaboration continuum, the level of engagement between collaborators moves from low to high and the level of interaction moves from infrequent to intensive (Austin, 2000). We explore in our analysis whether more intensive collaboration result in more comprehensive disclosure.

Based on our discussion of social movement theory and the role of social movement activism, our second hypothesis suggests that protest, as an extra-institutional activity by stakeholder groups such as social movement organisations, influence organisational decision making (e.g., Gamson, 1989; King et al., 2007; King and Soule, 2007). Protest is an interesting part of stakeholder pressure that has not been considered in prior accounting research (but see stakeholder pressures in Roberts, 1992; Islam and Deegan, 2008). King and 
Soule, (2007) argues that protest is a viable tactic to influence corporate behaviour. Activist (NGO) protests via picketing, demonstrations, boycotts, campaigns, etc., is a natural social movement tactic used to call for the involvement of various audiences in the change process, and hence this can be considered as the 'dominant mode of governance' to discipline corporations (King and Soule, 2007, p.415). In line with these arguments (i.e., particularly with reference to King and Soule, 2007; King, 2008) we regard 'protest' as a particular form of social movement activism and propose the following hypothesis:

$\mathrm{H}_{2}$ : The comprehensiveness of disclosures on conflict minerals is enhanced by activist protest against corporate activities regarding conflict minerals.

Carberry et al. (2017) suggest that both activist protest and NGO collaboration impact organisational practices. While activist protests are more effective at influencing indirectly by transforming organizational fields (i.e., protest mostly create change at the field level), NGO collaborations directly influence corporate managers (i.e., NGO collaboration create change at the firm level). Given our hypotheses that both collaboration and protest have a positive impact on corporate disclosure, we are interested in how these factors interact. While activist protest as an extra-institutional force indirectly influence corporate practices (King and Soule, 2007; King, 2008), it may in particular influence corporations to collaborate with NGOs which in turn influence corporate disclosure practices. While activist protest appeals to third parties or news media by broadcasting grievances publicly (King, 2008), as a response to such protests, NGO collaboration could be more effective to create change in corporate accountability and disclosure practices. We therefore consider whether collaboration and protest action interact and influence the comprehensiveness of disclosure in this way, i.e., NGO collaboration may have more influence on the comprehensiveness of disclosure for companies that experienced protest action. We therefore propose the following hypothesis:

$\mathrm{H}_{3}$ : Collaboration with social movement NGOs has a bigger impact on the comprehensiveness of corporate conflict mineral disclosures, if activist protest against corporate activities regarding conflict minerals is present

\section{Research methods}

This study focuses on companies forming part of the 2014 Forbes Global 2000 companies that are involved in electronics reliant industries. ${ }^{8}$ Griffin et al. (2014) indicate that conflict

\footnotetext{
8 The Forbes Global 2000 consists of the world's biggest public companies. Forbes compile their Global 2000 list using four metrics: sales, profits, assets and market value. Each of the Global 2000 metrics has a minimum
} 
minerals are essential for a wide range of consumer products including auto parts, cell phones, jet aircraft, products with integrated circuits and capacitors (almost all consumer electronics), medical equipment, and products using solder for metal joints. We identified 475 companies as electronic reliant companies and out of them 139 companies were listed on US stock exchanges and submitted conflict mineral reports to the SEC in 2014. ${ }^{9}$ Of these, 95 companies (68\%) are based in the USA and the rest of the companies are based in European and developing countries (including China). Reporting on conflict minerals were reviewed to ascertain the comprehensiveness of the disclosures. The conflict mineral reports were collected from the SEC website. ${ }^{10}$

\subsection{Conflict mineral disclosures}

We developed a disclosure index to document the comprehensiveness of the disclosures. In developing the different elements of disclosure for our index, we considered the disclosure requirements within the Dodd-Frank Act and the OECD's due diligence guidance addressing conflict minerals (basic guidance was discussed in section 3 above). We used prior CSR disclosure research to determine the nature of the disclosure items in our disclosure list (i.e., our index). However, the disclosure items in our index are new in nature in so far as there is no known research that looked at these items with regards to evaluating the comprehensiveness of the disclosure on conflict minerals. Nine specific disclosure items are considered in our index and a scale was applied to assess the comprehensiveness of the disclosure for each item (See Table 1).

We assess the level of comprehensiveness of disclosures, following recent studies in the literature. ${ }^{11}$ For example, Beattie (2014) considered the level of comprehensiveness of disclosure as a proxy for quality of disclosure, while Van Staden and Hooks (2007) quantified the comprehensiveness of disclosure using an index of items and a quality scale. Beattie (2014, p. 113) stated that key characteristics of the quality disclosure index approach

cut-off value in order for a company to qualify: sales $\$ 4.16$ billion, profits of $\$ 267.0$ million, assets of $\$ 8.57$ billion and market value of $\$ 5.49$ billion. A company needs to qualify for at least one of the metrics in order to be eligible for the final Global 2000 ranking.

${ }^{9}$ There was some missing data for the control variable CSR Performance (see Table 4), leading to a sample of 133 companies for which all the data was available.

${ }^{10}$ See website at: https://searchwww.sec.gov/EDGARFSClient/jsp/EDGAR_MainAccess.jsp? search_text $=* \&$ sort $=$ Date $\&$ formType $=$ FormSD\&isAdv $=$ true \&stemming $=$ true $\&$ numResults $=10$

${ }^{11}$ In a supplementary test we use the extent of disclosure as a proxy for comprehensiveness in recognition of the earlier (CSR) disclosure research that focused on extent measures (i.e., words and sentences). However, we find that comprehensiveness is a better measure for our purpose. 
may 'include (i) whether each item is measured in simple binary (i.e. presence/absence) terms [see for example, Islam and McPhail, 2011] or an ordinal measure is used to try to capture quality aspects [see Cannizzaro and Weiner (2015) as example]; and (ii) whether each item is weighted or unweighted [see for example, Van Staden and Hooks, 2007]'. Cannizzaro and Weiner (2015) evaluated disclosure comprehensiveness by categorising disclosure items into three categories: full disclosures, partial disclosures and minimal disclosure, while Van Staden and Hooks (2007) used a five point scale which gives a higher weighting to more comprehensive disclosures. We take a similar approach and used a scale of 0/1/2 (where 0 means no disclosure, 1 means minimal disclosure and 2 means high level comprehensive disclosure - the scale is applied to each item in Table 1). Our approach is similar to prior research assessing the comprehensiveness (quality) of voluntary CSR disclosures (see for example, Clarkson et al., 2008, Van Staden and Hooks, 2007, Cho et al., 2015). Beattie's (2014) review confirm that recent studies have used scale based disclosure indices.

The details of the coding guide, including the index items and the scale, are provided in Table 1. An expert content analyst reviewed the reports and completed the coding. Another member of the project verified the expert's coding process by reviewing the first twenty coded conflict mineral reports.

\section{$<<$ Insert Table 1 >}

We base our content analysis on the first reports filed with the SEC as at 31 May 2014 (covering products manufactured from 1 January 2013). The maximum possible disclosure score a company may have is 18 . However, as shown in Table 2, the highest score obtained was 12 . Only four companies have scored 12 . The majority of the companies have scored between 4 and 9 (mean 5.727). The last column of Table 2 shows the average disclosure score for each of the nine specific issues, being the mean score of each item divided by the maximum possible score for that item (see also Table 1). Management commitment and Due diligence issues received the highest scores.

\section{$<$ Insert Table $2>>$}

\subsection{Collaboration with social movement NGOs (NGOCollab)}

Arenas et al. (2009) argue that 'new' forms of collaboration between NGOs and corporations promote social and environmental actions, design corporate social responsibility standards and reporting processes, participate in monitoring activities and provide technical assistance to corporations. These forms of collaboration are intensive and engaged. In this type of collaboration both parties aim to create corporate social transparency and legitimacy and 
maintain their reputation and public image (Rondinelli and London, 2003). In this paper, we examine the impact of engaged and intensive collaborations between social movement NGOs and corporations on the transparency of disclosures relating to conflict minerals. ${ }^{12}$

Following the Dodd-Frank act, social movement organizations are seen to collaborate with companies to monitor and provide skills and resources to assist companies to identify and eliminate conflict mineral sources, and report on the process. We define the nature of this level of collaboration as specific, intensive and engaged (Rondinelli and London, 2003; Mandell, 1999; Austin, 2000). Such collaboration appears to influence conflict mineral disclosures because one of the key aims of the collaboration is to create social transparency and provide solutions for transparency related problems within supply chains. The main purpose of collaboration with social movement NGOs is involvement in monitoring activities (including assisting with internal control issues) and relatively permanent organised efforts to identify and eliminate conflict minerals and ensure transparency within supply chains. We identified four major NGO collaborators of our sample firms and provide more details of these collaborators in Appendix 1.13

The collaborations across the four NGOs range from less intensive and engaged to more engaged, intensive and task specific, as explained in the Appendix. Among the four major NGO collaborators considered in this study, CFSI's collaboration with electronic companies is more engaged, intensive and task specific than any of the others. CFSI and companies come 'together out of a joint concern about addressing a particular social problem' (Austin, 2000, p. 77), this being the elimination of human rights issues within conflict mineral zones.

The data on collaboration with NGOs have been collected from the company annual reports, websites and conflict mineral reports. We complemented this data by going to the websites of the four main collaborating NGOs in this area and using the lists of collaborating companies from these websites to verify and extend our list of collaborating companies. We identified whether each company in our sample collaborated with social movement NGOs on

\footnotetext{
${ }^{12}$ Some examples of intensive and engaged collaboration from Rondinelli and London (2003, p. 65) include: NGOs seeking to prevent pollution and environmental damage before it occurs by working more directly with companies to change their products or processes, and companies working with the Alliance for Environmental Innovations to improve internal operations, for example, reduced energy, resource use and pollution.

${ }^{13}$ Detail membership (corporate collaborators) of movement organizations can be viewed at EICC- Electronic Industry Citizenship Coalition <http://www.eiccoalition.org/>; CFSI - Conflict-Free Sourcing Initiative <http://www.conflictfreesourcing.org/about/>; GeSI - Global e-Sustainability Initiative <http://gesi.org/>; and AIAG - Automotive Industry Action Group <http://www.aiag.org/about> (last viewed on 12/06/2016).
} 
conflict minerals during the year before 31 May 2014. In these sources, companies recognise who they collaborate with in terms of transparency initiatives. For example, Sony mentioned on its website:

"It is also Sony's policy to require its suppliers to source materials from smelters determined to be compliant with the Electronic Industry Citizenship Coalition (EICC)/Global eSustainability Initiative (GeSI) Conflict-Free Smelter (CFS) Program protocols, or other smelters that have been determined to be conflict-free smelters or determined to be conflictfree under other trusted traceability projects. The smelters identified by our direct suppliers were then compared against the conflict-free smelter list prepared by the Conflict-Free Smelter Initiative (CFSI) established by the EICC/GeSI, to further enhance the accuracy of Sony's findings" (see, http://www.sony.net/SonyInfo/csr_report/sourcing/materials/).

Further examples of disclosures of collaborations within the conflict mineral reports include:

"EMC is an active participant in the CFSI, engaging in workgroups and projects to advance both the CMRT and the CFSP. This collaboration helps us advance toward our goal, and it also helps to build a global supply chain system for responsible and ethical mineral sourcing that makes it more widely possible for companies to source DRC Conflict-Free minerals for their products" (EMC Conflict Mineral Report for the year ended Dec 31, 2013, p. 1).

"In January 2012, JEITA signed a Memorandum of Understanding (MOU) with the Electronics Industry Citizenship Coalition (EICC) and the Global e-Sustainability Initiative (GeSI) and agreed to collaborate in addressing conflict minerals issues. EICC and GeSI set up the Conflict-Free Sourcing Initiative (CFSI) as a structure to address these issues and created the Conflict Free Smelter (CFS) program. This program starts with the audit of smelters and refiners and is expected to be used as a means to validate trading from there through the downstream supply chain by inspecting whether conflict minerals that fund armed groups have entered the supply chain. JEITA participates and cooperates with the CFSI and Kyocera cooperates with the CFSI as a principal member of JEITA while also making use of the CFS program" (Kyocera Group Conflict Mineral Report for the calendar year ended Dec 31, 2013, p.3).

In terms of collaboration by the companies in our sample, we find that 65 of the 139 companies (47\%) had a collaboration with an NGO while 74 (53\%) had no collaboration. Furthermore, 37 companies had more than one collaboration (and two had more than two), i.e., $57 \%$ of those who collaborated had more than one collaboration. Having a sample with almost the same number of companies collaborating and not collaborating with NGOs, gives us the opportunity to investigate the effect of collaboration on the disclosure quality while also controlling for other factors influencing disclosure quality. The extent of collaboration (i.e. the number of collaborations) is our preferred measure of the intensity of collaboration as it is an interval scale rather than a dichotomous indicator; does not discard information and hence reflects information on more intense collaborations rather than just collaborating or not, and so provides a more nuanced view of the relationship with disclosure. ${ }^{14}$ We therefore use the extent of collaboration as our collaboration measure (NGOCollab).

\footnotetext{
${ }^{14}$ In addition, we could not run a test with the dummy variable 'existence of collaboration' - according to Angrist and Pischke (2009. p. 190) it is a mistake to apply 2SLS or 3SLS directly if the endogenous variable is a
} 


\subsection{Activist protest (Protest)}

Protests vary in the nature of information they communicate: a boycott may have its own disruptive effects on the corporation, other protests such as demonstrations may draw attention to media and existing stakeholder concerns and may cause stakeholders to question firms' irresponsible behaviour (King and Soule, 2007). Larger or more frequent protests have a greater impact because of the disruption to the organisation's routine activities (Luders, 2006; King and Soule, 2007). While media attention itself has an effect on corporate practices including disclosure practices (Brown and Deegan, 1998; Islam and Deegan, 2010), protests highlighted in the media has even greater influence on corporate accountability practices. Activists and NGOs use the media to highlight their boycotts and protests to encourage corporate social accountability (Deegan and Islam, 2014). Protests and negative media attention regarding social and human rights issues appear to have bigger impacts on corporate behaviour than protests to protect the environment (King and Soule, 2007; Islam and Deegan, 2010; Deegan and Islam, 2014). Data on protest events were collected from media articles from the Dow Jones Factiva database and media articles and NGO reports available in the online resources in the Business and Human Rights Resource Centre (BHRRC), ${ }^{15}$ a London based global NGO. We used search keywords including 'protest', 'boycott', 'demonstration', 'campaign', 'NGO', 'activist', 'human rights', 'conflict minerals', and 'supply chains' to identify relevant media articles and NGO reports on each company within our sample. After we identified relevant articles and reports, we then read through each of the media articles and NGO reports to identify the number of 'protest events' for the companies in our sample. Our data collection approach is consistent with Islam and Deegan (2010) and King and Soule (2007).

\subsection{Control variables}

Prior research on CSR disclosures has shown that there are many factors that could influence the extent and comprehensiveness of CSR disclosures. Seeing that conflict mineral disclosures could be classified as CSR disclosures, we use similar control variables in our

dummy variable. We can also not use OLS tests as OLS can produce biased and inconsistent parameter estimates in the presence of an endogenous variable. We found that the collaboration variable is endogenous using a Hausman test, see below.

${ }^{15}$ BHRRC tracks the human rights performance of over 6000 companies in over 180 countries, making information provided by the media and NGOs publicly available. 
model. We therefore control for the effects of CSR performance, size, industry, profitability, other financial and market measures (i.e., leverage, volatility and Tobin's Q) and country measures. Table 3 shows a summary of all our variables, including the source and calculation of the variables.

CSR performance (CSRPerf). We know from the CSR literature that there is a relationship between CSR disclosure and CSR performance (see for example, Patten, 2002; Al-Tuwaijri et al., 2004; Clarkson et al., 2008; Silva-Gao, 2012). We argue that corporate social responsibility (CSR) performance could influence conflict mineral disclosure. Since environmental, social and governance (ESG) performance demonstrate a commitment to CSR and therefore to the elimination of socially unacceptable practices like the use of conflict minerals, we use the ESG performance measure from the Bloomberg database as a performance measure in our study. The Bloomberg ESG score ranges from 0 to 100 and is determined based on a whole range of indicators in each of the three areas. In the environmental area (E), this is based on 119 items which include items on verification, emissions intensity, resource consumption and supply chain management. In the social area (S), this is based on 45 items which include items on accidents and fatalities, operational policy and supply chain issues. In the governance area $(G)$, this is based on 96 items which include items on board structure and independence, board committees and shareholder rights. These measures are designed to capture actual performance in each of the areas, rather than just policies and intentions. ${ }^{16}$ In sensitivity tests we also use other social performance measures.

Company size (SIZE). Large companies have a greater societal impact (Hackston and Milne, 1996; Patten, 2002). Since they are more visible, they face more stakeholder pressure to demonstrate their social responsibility (Aerts and Cormier, 2009). In line with other studies in the literature (De Villiers and Van Staden, 2011; Clarkson et al., 2008), we use the natural logarithm of total assets as SIZE. Since our sample is drawn from the biggest companies in the world, size may not be an influence for this group of companies. However, we nevertheless include the size measure as it is so widely used in disclosure studies.

Industry. We divided the sample into five industries based on the Global Industries Classification Standard (GICS) sector name. We have the following industries in the sample:

\footnotetext{
${ }^{16}$ Bloomberg ESG data captures standardized cross-sector and industry-specific metrics. Although Bloomberg, like KLD, uses corporate reports as an input to their ratings, they augment this with other formal and informal sources of information including evaluations by the United Nations and media reports (see also Cahan et al, 2016).
} 
Information Technology and Telecommunications $(\mathrm{N}=67)$; Industrials $(\mathrm{N}=23)$; Energy $(\mathrm{N}$ =17); Healthcare $(\mathrm{N}=16)$; and Consumer Discretionary $(\mathrm{N}=16)$. We include a dummy variable for each of these industries in our model.

Financial performance and position (ROA, LEV, TOBIN Q, and VOLAT). Profitability is seen as a determinant for CSR news exposure (see for example, Aerts and Cormier, 2009; Alrazi et al., 2016). Profitable firms are more likely to voluntarily disclose social and environmental information to manage their image as socially responsive. We measure profitability by return on assets $(R O A)$, calculated as the ratio of net income before extraordinary items to total assets (Clarkson et al., 2008, De Villiers and Van Staden, 2011).

Since social and environmental issues can affect the financial stability of an organization, Roberts (1992) asserts that highly leveraged firms will face greater expectations from creditors to observe their social responsibility activities, including initiatives to deal with conflict minerals. Therefore, they would be expected to provide more extensive disclosures. LEV, our measure of leverage, is calculated as average total assets divided by average total common equity, i.e., financial leverage.

Tobin's Q (TOBIN $Q)$ could represent the level of intangible assets in a firm as well as the long-term value of the firm (Cahan et al., 2016). While companies with a higher composition of intangible assets in relation to physical assets could be less polluting (see for example, Al-Tuwaijri et al., 2004; Clarkson et al., 2008; De Villiers and Van Staden, 2011) these companies could still face social issues like the use of conflict minerals. While some studies suggest that companies with a lower Tobin's Q would be disclosing more environmental information than firms with a higher Tobin's Q (see for example, Clarkson et al., 2008; De Villiers and Van Staden, 2011) it is not clear what the relationship between Tobin's Q and social disclosures would be. We nevertheless include it following its inclusion in environmental studies in the literature. TOBIN $Q$ is measured as the market value of the shares plus the value of preference shares, long term debt and current liabilities, divided by total assets.

We also assess the financial position of each company based on its share price volatility $(V O L A T)$. Erratic share price movements could indicate financial instability and engaging in socially and environmental irresponsible behaviour would further add to the riskiness as an investment. In this sense, there would be a greater pressure for 'volatile' companies to demonstrate social and environmental responsibility. VOLAT is measured as the standard deviation of market adjusted daily share returns during the year. 
Country. Since only companies listed on a US exchange will file a conflict mineral report with the SEC, all companies in the sample are listed in the US. However, not all the companies are US companies. We distinguish between the US (95), Europe (25), Japan (6) and the rest of the world (13) (i.e., countries with less than 5 companies). We include a dummy variable for each of these countries in our model.

$$
<\text { Insert Table } 3>>
$$

We use the Hausman test to test for endogeneity. We find that NGO collaboration $\left(\right.$ NGOCollab) is endogenous $(\mathrm{p}=0.020)$ while protest events $($ Protest $)$ is not $(\mathrm{p}=0.991) .{ }^{17}$ Since we find endogeneity in our main variable of interest, we use three stage least square analysis (3SLS) for our main analysis. We use the following model to test our hypothesis:

Disclosure $=a_{1}+B_{1}$ NGOCollab $+B_{2}$ Protest $+B_{3}$ NGOCollabXProtest $+B_{4}$ CSRPerf $+B_{5}$ SIZE + $B_{6} R O A+B_{7} L E V+B_{8} T O B I N Q+B_{9} V O L A T+\sum_{10}^{13} B_{i}$ Industry $+\sum_{14}^{16} B_{j}$ Country

\section{Results}

\subsection{Descriptive statistics}

Table 4 shows descriptive statistics for all the variables.

$$
<\text { Insert Table } 4>>
$$

The mean disclosure score is $31.82 \%$ with a minimum score of $5.55 \%$ and a maximum score of $66.67 \% .^{18}$ The mean collaboration with social movement NGOs (NGOCollab) is $0.75(\min 0, \max 3)$. For the protest measure (Protest) the mean number of protest events is $1.31(\min 0, \max 24)$.

The mean for performance in the CSR area (CSRPerf) is 35.99 (min 5.37, max 83.06). The average assets for companies in the sample (SIZE) is $\$ 50,5$ billion ( $\min \$ 1,7$ billion, max $\$ 656,5$ billion). Average return on investment $(R O A)$ is $8.08 \%$, average leverage $(L E V)$ is 3.06 and average Tobin' $\mathrm{Q}(T O B I N Q) 1.89$ with an average volatility (VOLAT) of 25.54 .

\footnotetext{
17 The STATA statistical analysis function treat all exogenous variables as instrumental variables in the 3SLS analysis. The following variables are therefore instrumental variables: Protest, CSRPerf, SIZE, ROA, LEV, TOBIN Q, VOLAT, Industrials, Energy, Healthcare, Cons Discr, Europe, Japan, Rest.

${ }^{18}$ In our analyses we use a disclosure score out of 100 , based on the actual score obtained for the nine items over the maximum possible score, multiplied by 100 .
} 


\subsection{Correlations}

Table 5 provides correlation measures. A review of the correlation statistics indicates that, as expected, at the bivariate level, collaboration (NGOCollab) and activist protest (Protest) are significantly (and positively) associated (at the 1\% level) with more comprehensive disclosure scores. The interaction between collaboration and protest (CollabXProt) is also significantly associated (at the $1 \%$ level) with more comprehensive disclosures. Table 5 also indicates that some of the control variables are significantly associated with disclosure, which is a good reason for doing multivariate analysis. The correlations are not high enough to suggest a problem with collinearity - the highest correlation being 0.695 between ROA and Tobin's Q.

\section{$<$ Insert Table $5>>$}

To focus further on the intensity of collaboration, we distinguish between companies that collaborated with the CFSI and those that collaborated with other NGOs. We argued before that collaboration with the CFSI is more engaged, intensive and task specific. We note that 47 companies collaborated with the CFSI while 39 companies collaborated with EICC, 12 with GeSI and 6 with AIAA. ${ }^{19}$ From Table 6 it is clear that those who collaborated had a significantly higher mean disclosures score (36.15) than those who did not. If we split the sample further between CFSI and other collaborations, we find that those who collaborated with CFSI had a significantly (at the 5\% level) higher mean disclosure score (37.77) than those with other collaborations (31.94). While both of these are significantly higher than the disclosure score of those that did not collaborate (22.03), it is clear that collaboration with CFSI lead to more comprehensive disclosures compared to other collaborations. More intense, engaged and task specific collaboration therefore improves the comprehensiveness of the conflict mineral disclosures.

\subsection{Means analysis}

We did a number of means tests which gave some interesting results - see Table 6. Firstly we compared companies that had NGO collaboration with those that did not and find that the mean disclosure score of those that collaborated is significantly higher $(p=0.000)$ than those

\footnotetext{
${ }^{19}$ The 65 companies that collaborated had 104 collaborations between them as $57 \%$ of those who collaborated had more than one collaboration.
} 
who did not collaborate. The mean number of protest events is also significantly different ( $p$ $=0.006$ ) between those that collaborated and those who did not, suggesting that protest leads to collaboration. Furthermore, there is no significance difference in the mean CSR performance measure between those that collaborated and those who did not.

Next we split the sample on the basis of those who had above average disclosure scores versus the rest. For those with above average disclosure scores we find that the mean collaboration level is significantly higher $(\mathrm{p}=0.001)$ and the mean number of protest events are also significantly higher $(\mathrm{p}=0.001)$. There is no significant difference in the mean CSR performance between these two groups.

Finally we split the sample between US and non-US companies. Surprisingly we find that US companies have on average significantly lower average CSR performance $(p=0.001)$ than non-US companies. However, there is no difference between the disclosure scores, protest events and collaboration levels of US and non-US companies. Our results are therefore not driven by US companies.

\section{$<<$ Insert Table $6>>$}

The means tests therefore provide bivariate evidence that protest is strongly associated with collaboration which, we suggest, then influences the comprehensiveness of disclosures. Therefore those who experienced protest both collaborated and had better disclosure scores, we would argue because of the collaboration. More comprehensive disclosure is therefore the result of collaboration, but not of CSR performance or being a US company. Also US companies do not collaborate more or less, or experience more protest action than the other companies in the sample. In the next analysis we will be considering these factors together in a multivariate regression analysis.

\subsection{Regression analysis}

The results of the three stage least squares analysis are reported in Table 7. NGO Collaboration (NGOCollab) is highly significant and positive and so is protest events (Protest). The interaction between collaboration and protest (NGOCollabXProtest) is also significant, but the effect (coefficient) is negligible.

For the control variables we see that profitability is significant and positive at the $5 \%$ level while companies with less leverage also have more comprehensive disclosures, at the $10 \%$ level of significance. None of the other financial control variables are significant.

Companies in the Healthcare industry have more comprehensive disclosures at the $10 \%$ level 
(than the control industry, Information Technology and Telecommunications). In terms of the country variables, companies from the rest of the world have less comprehensive conflict mineral disclosures at the $5 \%$ level (than the control country, the USA).

$<<$ Insert Table $7>>$

\subsection{Discussion of results}

Given the indications from the bivariate correlations (Table 5) and the test of means (Table 6) and the strong results from the multivariate 3SLS regression (Table 7) (which controls for other factors that could influence the quality of disclosure, including protest events and CSR performance) our analysis suggest that collaboration with NGOs has a positive and highly significant influence on the comprehensiveness of conflict mineral disclosures. While we cannot of course claim to have demonstrated causality, we have controlled for potential endogeneity of variables of interest and the model results show strong associations and thus are consistent with our hypothesis of causality. Hypothesis 1 is therefore strongly supported.

We find that NGO protest events also have a significant influence (at the 5\% level) on disclosures. We note this from the correlations (Table 5) the means test (Table 6) and the 3SLS analysis (Table 7). This provides support for Hypothesis 2.

Seeing that both collaboration and protest are significantly related to disclosure, we analyse this relationship further. From Tables 5 and 6 we can see that protest is significantly related to collaboration, so could protest influence disclosure through collaboration? From our correlation test (Table 5) we note that the interaction between NGO collaboration and protest action (NGOCollabXProtest) has a very significant positive effect on disclosure $(\mathrm{R}=$ $0.564 / 0.425$ at the $1 \%$ level) while our 3SLS analysis (Table 7) show that the interaction is significant at the $5 \%$ level, indicating that as collaboration and protest increase, disclosure increases. However, while significant, the effect is negligible. ${ }^{20}$ There is therefore some support for Hypothesis $3 .^{21}$

What makes the biggest difference? Analysing the marginal effects of these three variables shows that the marginal effects are more strongly driven by NGOCollab (coefficient

\footnotetext{
${ }^{20}$ The interaction variable is of statistical significance and important to include in order to avoid the omitted variable problem, but the practical effect of the interaction is not really important.

${ }^{21}$ Furthermore, if we compare the coefficient for collaboration (NGOCollab) before we add the protest variable (4.559 - untabulated) with the coefficient including protest (19.433 - Table 7) it suggests that collaboration has a bigger impact on the comprehensiveness of disclosure when protest is present (i.e., an increase in collaboration will increase the comprehensiveness by $19.43 \%$ when protest is present vs. $4.56 \%$ if it is not present). However, we acknowledge running the 3SLS without the protest variables could result in biased results due to omitted variable bias in the model without protest.
} 
19.433; p-value 0.000) than Protest (coefficient 9.244; p-value 0.015) and the interaction of collaboration and protest, although statistically significant, cause a very small attenuation of the effect (coefficient 0.769; p-value 0.017). One unit change in NGOCollab therefore has a much bigger increase in disclosure quality than a unit change in Protest and in both cases the influence of the interaction (NGOCollabXProtest) has no material influence on the marginal effects.

\subsection{Further analysis for robustness}

\section{Using a different disclosure measure}

While we use the comprehensiveness of disclosure as the disclosure measure in our main analysis, we are aware that some research in the CSR area use extent measures for disclosure (i.e., word, sentences, pages). We have motivated comprehensiveness as the best option from the current CSR/content analysis research. However, the decisions involved in allocating a score to a disclosure is arguably more subjective than to just count the number of words, sentences, and/or pages in a conflict mineral report. Therefore, as a sensitivity test we collected extent measures and replace the disclosure score in our main analysis with an extent measure.

We note firstly from a correlation analysis that the extent measures are highly correlated to each other, as would be expected. Words lead to sentences $(R=0.860)$ and to pages $(\mathrm{R}=0.898)$. Furthermore, our disclosure score is related to extent (i.e., with sentences $\mathrm{R}=0.74$ ). This can be explained in that to do comprehensive reporting in the conflict mineral report will require more sentences. Companies will not be able to comprehensively report on the items in our index using only a few sentences. This was also found by Hooks and Van Staden (2011, p.11) “....if companies wanted to address all the areas covered by [a] quality assessment index, a large number of sentences were required. Therefore, it is not surprising that the correlation between extent and quality was high."

When we replace our disclosure score with an extent measure (sentences), we observe that our results remain qualitatively the same. ${ }^{22}$

\footnotetext{
${ }^{22}$ In this and the other additional tests, 'qualitatively the same' means that the results, while not having exactly the same numeric values, have the same qualities, i.e., collaboration, protest and the interaction term have the same (level of) statistical significance and show the same coefficient differentials as in the main analysis. The marginal effects therefore continue to be more strongly driven by NGOCollab than Protest; and the interaction of collaboration and protest has a negligible effect.
} 


\section{Using different measures for CSR performance}

In our main analysis we use the ESG measure from the Bloomberg database as our CSR performance measure. In our sensitivity analysis we use a lead (ESG2014) and lag (ESG2012) measure. Again the results remain qualitatively the same.

Next we construct another CSR performance measure from the Bloomberg data. We use a combination of four measures: Social Supply Chain Management (SSCM); Sustainability Supply Guidelines (SSG); Anti-bribery Ethics Policy (AEP); and Business Ethics Policy (BEP). Since all four these items were measured as 1 or 0 by Bloomberg, we calculate an average over the four measures as our Combined Ethics Score (CES). Replacing the ESG variable with our CES variable results in qualitatively similar results.

We also replaced the ESG variables with the components E (Environmental score), S (Social score) and G (Governance score) respectively and again find qualitatively similar results to the main analysis.

The different CSR performance measures that we used in robustness tests, show that our model is robust to different measures of CSR performance.

\section{Using different size measures}

Since different size measures are highly correlated with each other, we could not use more than one of these in the same model. In our main model we use the natural log of total assets as the size measure. We also ran the model using sales and market value as size measures. Again, following the literature in the area, we use the natural log of these measures as they are not normally distributed. The results remain qualitatively the same as the main results. The size measures are not significant. This shows that our model is robust to different measures of size.

It is interesting that size does not affect the disclosure results as it is often implicated in the literature as a driver for (voluntary) disclosure. We note from the correlation table (Table 5) that size is significantly correlated (at the $1 \%$ level) with Protest (i.e., bigger companies attract more protest), but not with collaboration and disclosure. ${ }^{23} \mathrm{~A}$ few explanations comes to mind. Firstly our sample is from the biggest companies in the world (the Forbes Global 2000 companies, see footnote 7), so size may not have an effect if the sample consist of very large companies. Second, conflict mineral disclosure is required for

\footnotetext{
${ }^{23}$ Bigger companies also have better CSR performance but lower profitability, Tobin's Q and volatility.
} 
US listed companies, so the size effect on the disclosure decision is obviously not relevant, and it seems like the size effect on disclosure comprehensiveness (quality) is not significant in these circumstances.

\section{Using a different country measure}

Instead of the three country measures we use in the main analysis, we also run the regression using a country variable indicating if the companies are from the US or not. Our results remain qualitatively the same. The country variable is not significant suggesting that US companies do not make more comprehensive conflict mineral disclosures compared to other countries.

\section{Discussion and conclusions}

The elimination of conflict minerals from the supply chains of US companies is a major social justice issue. Disclosure of the existence of conflict minerals in the supply chain would be an important step in the elimination process. Supply chain disclosures in accordance with the Dodd-Frank Act, is therefore an important issue. Following social movement theory and the theory of collaboration, we are interested to determine if the comprehensiveness of disclosures on conflict minerals is influenced by social movement activities to create corporate transparency regarding conflict mineral use. While the Act requires a minimum level of disclosure, the literature suggests that the comprehensiveness of both voluntary and mandatory disclosures is subject to a range of internal and external influences. Using a disclosure index derived from the requirements of the Dodd-Frank act and the OECD guidelines for conflict mineral supply chains, we investigate the roles of NGO collaboration and activist protest with respect to the comprehensiveness of conflict mineral disclosures by 139 of the largest global electronic reliant companies. We find that collaboration with NGOs, as social movement organizations, and activist protest lead to more comprehensive and therefore more transparent disclosures. Our findings suggest that NGO collaboration with corporations has a higher impact on corporate conflict mineral disclosures if activist protest against corporate activities regarding conflict minerals is present. Similarly, the marginal effects on disclosure are more strongly driven by NGO collaboration than activist protest, indicating that one unit of change in the intensity of NGO collaboration has a much bigger increase in disclosure comprehensiveness than a unit change in protest action. Our findings in particular suggest that engaged collaboration with social movement NGOs 
improve corporate transparency, even for a mandated disclosure, i.e., conflict minerals in corporate supply chains.

We use a combination of social movement theory and the theory of collaboration to understand the disclosure practices. Social movement theory is a widely used theory in sociology and organizational studies. Although organizational sociologists have become more interested recently in social movement theory as a way of thinking about causes of organizational change (King and Soule, 2007), research has not sufficiently addressed how NGOs as organizational outsiders effect the transparency of disclosure practices. Like many other stakeholders (for example the news media), NGOs lack access to the conventional avenues of corporate decision making, but they have gained influence in the realms of society through their protest actions and collaborations. The originality of this paper relates to an examination of an alternative mechanism (protest and collaboration) to influence companies' transparency. While social movement theory explains the notion that NGOs can influence organizational practices, collaboration theory suggests that organizations respond and conform to the influences of social movement NGOs through collaboration, and that in turn results in more comprehensive and transparent disclosures.

This study addresses an important research problem by investigating the role of NGOs in corporate disclosure practices. Prior research, considered the roles of different stakeholders (see for example, Deegan, 2002; O'Sullivan and O'Dwyer, 2015), but does not systematically explain whether and how a company conforms to the expectations of the broader community which are manifested by NGO actions, i.e., their collaboration with companies and/or their independent (protest) actions. A discussion of disclosure practices, as a part of the response to NGO influence, is missing in the accounting research. The findings of this paper make it clear that collaboration with NGOs as outsiders can have a real influence in the corporate transparency sphere. Their role as outsiders gives them a unique opportunity. NGOs, through their protests/campaigns and collaborations, act as extra-institutional actors, with the goal of changing corporate practices. Within the accounting literature, we see how extra-institutional actors such as the media influence corporate disclosures. Research in understanding the role of NGOs is therefore important. In particular if researchers wish to investigate corporate reporting on human rights, the role of social movement NGOs' should not be ignored.

Our findings have implications for those who study corporate accountability practices within supply chains. There is little research focusing on accountability issues within supply chain management. As NGOs play an active role in the construction of changing corporate responsibilities (O'Sullivan and O'Dwyer, 2015), there is a possibility that companies translate 
such stakeholder concerns into their core accountability and disclosure practices. One of the main implications of our findings is that companies may gain tactical value by paying attention to societal actors/stakeholders who may not have direct investment in the companies. That is, if companies do not collaborate with these NGOs to change their transparency and accountability, they may run the risk of giving them reasons to express their grievances publicly, at which point the companies may lose control of the issue to the public and thereby loose legitimacy. We show the link between social movement action through NGOs and the comprehensiveness of corporate supply chain disclosures, but the implications could be broader in terms of companies' image, reputation and legitimacy.

Given the disclosure regulations in place (the Dodd-Frank Act), it is obvious that companies would disclose information in order to comply with the regulations. But the implications of this paper is that while the regulations influence disclosure (minimum disclosure), the variations of extent and comprehensiveness of disclosure that we have observed in this study cannot simply be explained by regulation. We find that it is the actions of social movements that lead to the variations of disclosures. The role of social movements, including public support, therefore creates a new environment where regulators and companies respond. The SEC rules will eventually affect at least six thousand issuers, which is about half of all publicly traded companies in the United States. We are of the opinion that our results could also apply to any country that implement similar legislation, e.g., the UK Modern Slavery Act 2015 and the EU Conflict Minerals regulation of 2017. Our study has implications because the conflict minerals rules (section 1502) and the influence of social movements revisit the question of "materiality to market players such as shareholders" in that social movements influence the level of disclosures regardless of materiality in the eyes of shareholders. The rise of the social movement NGOs has shifted the paradigm away from accounting and financial information only, demanding more transparency on issues of human rights and social responsibility.

This study has some limitations. Although companies across different industries submitted conflict mineral reports to the SEC (KPMG, 2014), we looked at only companies within the electronic reliant industries. We found 139 large companies (within the Forbes global 2000 companies) from electronic reliant industries that submitted their conflict mineral reports to SEC as first time reporters. As we only look at companies within electronics reliant industries, the degree to which our findings can be generalized to other industries cannot be assessed. Furthermore, our disclosure index could have a level of subjectivity, similar to many other studies in the literature using disclosure indices. As a sensitivity test, we also used the 
extent of disclosure which is less subjective as it includes the full extent of the reports filed with the SEC.

We acknowledge that the cross sectional nature of our sample has some limitation in that we cannot claim to have demonstrated causality. However, we have controlled for potential endogeneity of variables of interest and the model results show very strong associations and thus are consistent with our hypothesis of causality. In addition we controlled for all known influences on disclosure in our model. The benefit of our use of the first reports is that it removes the effects of institutional isomorphism and shows the influence of collaboration at a time when the reporting requirements were still unfamiliar. Also, it takes away the question of whether disclosure influences collaboration and protest, as these were the first conflict mineral reports filed with the SEC. Expanding the study to a longitudinal analysis could be a valuable extension of this research. Diff-in-diff analyses on pre- and post- effects of having conflict mineral reports will also be a useful extension of this research.

When we evaluated the comprehensiveness of conflict mineral disclosures, we did not compare such disclosures with the actual actions conducted by collaborators as this information is not available in relation to conflict minerals. We are therefore not sure whether conflict mineral disclosures reflect real actions of the companies, or disclosures are fabricated (Preston et al., 1992), or disclosures are loosely coupled (decoupled) from real actions (Whiteman and Cooper, 2016) or even if the disclosures are simply greenwash (Delmas and Burbano, 2011). However, since the Section 1502 requires companies to disclose to the SEC and is subject to severe sanctions by the SEC for false or misleading filings, we anticipate less greenwash compared to voluntary disclosures in annual reports and on websites.

The implications of our findings are that voices of social movements (through NGOs) and their efforts to create change in corporate accountability should not be underestimated by corporate managers, corporate policy makers and regulators. Our findings open the possibility for further research to investigate how voices available to secondary stakeholders (NGOs, social movement organisations, activists, media) matter to hold corporations accountable to protect human rights. Our research also supports O'Dwyer and Unerman's (2016) call for more research on supply chain abuses. For capital market researchers, our research provides stimuli for further research to address the question: if NGO collaboration results in more comprehensive disclosure, how will this in turn affect value relevance. For critical researchers, it may be worthwhile to investigate how NGO social justice movements operate and how contestation on such movements is manifested (Martinez, and Cooper, 2017) in an attempt to create corporate transparency and accountability. On a more theoretical level, this study calls 
for further accounting and organizational research that will address the question of how extrainstitutional actors such as NGOs and other social movement organizations gain traction in society where there are a few legitimate platforms of influence.

\section{References}

Aerts, W. \& Cormier, D. (2009). Media legitimacy and corporate environmental communication. Accounting, organizations and society, 34(1), 1-27.

Angrist, J.D. \& Pischke, J. (2009). Mostly Harmless Econometrics: An Empiricist's Companion. Princeton University Press: Princeton.

AFLCIO (2011). Stop Sweatshops <http://www.aflcio.org/corporatewatch/stop/> (accessed 12 June, 2014).

Amnesty International (2015). Digging for transparency, Amnesty International, April <https://www.amnesty.org/.../AMR5114992015ENGLISH.PDF> (accessed 02 May, 2015).

Alrazi, B., De Villiers, C. J. \& Van Staden, C. J. (2016). The environmental disclosures of the electricity generation industry: a global perspective. Accounting and Business Research, 46(6), 665-701.

Al-Tuwaijri, S. A., Christensen, T. E. \& Hughes, K. E. (2004). The relations among environmental disclosure, environmental performance, and economic performance: a simultaneous equation approach. Accounting, Organizations and Society, 29(5), 447-471.

Arenas, D., Lozano, J.M. \& Albareda, L. (2009). The role of NGOs in CSR: Mutual perceptions among stakeholders. Journal of business ethics, 88(1), 175-197.

Austin, J.E. (2000). Strategic collaboration between nonprofits and business. Nonprofit and voluntary sector quarterly, 29(1), 69-97.

Bachman, S. (2000). The Political Economy of Child labour and its Impacts on International Business, Business Economics, 35(3), 30-41.

Beattie, V. (2014). Accounting narratives and the narrative turn in accounting research: issues, theory, methodology, methods and a research framework. British Accounting Review, 46(2), 111-134.

Bhimani, A. \& Ncube, M. (2006). Virtual integration costs and the limits of supply chain scalability. Journal of accounting and public policy, 25 (4), 390-408.

Blacconiere, W. \& Patten, D. (1994). Environmental disclosures, regulatory costs, and changes in firm value. Journal of Accounting and Economics 18 (3), 357-377.

Bowman, R. (2013). Companies need to step up to meet new conflict-minerals reporting rule. Forbes., Oct. 12 < http://www.forbes.com/sites/robertbowman/2013/12/10/companies-need-to-step-upto-meet-new-conflict-minerals-reporting-rule/> (accessed 14 July, 2015).

Bowman, R. (2014). Court ruling throws SEC conflict-minerals disclosure into 'limbo'. Forbes., March, 29, <http://www.forbes.com/sites/robertbowman/2014/04/29/court-ruling-throws-secconflict-minerals-disclosure-rule-into-limbo/> (accessed 14 July, 2015).

Bregman, R., Peng, D. X, \& Chin, W. (2015). The effect of controversial global sourcing practices on the ethical judgments and intentions of U.S. consumers, Journal of Operations Management, 36, 229-243.

Brown, N. \& Deegan, C., (1998). The public disclosure of environmental performance information-a dual test of media agenda setting theory and legitimacy theory. Accounting and Business Research, 29(1), 21-41.

BSR. (2010). Conflict Minerals and the Democratic Republic of Congo. <http://www.bsr.org/reports/BSR_Conflict_Minerals_and_the_DRC.pdf> (accessed 4 May, 2014).

Cahan, S. F., De Villiers, C., Jeter, D. C., Naiker, V. \& Van Staden, C. (2016). Are CSR Disclosures Value Relevant? Cross-Country Evidence. European Accounting Review, 25(3), 579-611.

Cannizzaro, A. P. \& Weiner, R. J. (2015). Multinational investment and voluntary disclosure: Projectlevel evidence from the petroleum industry. Accounting, Organizations and Society, 42, 32-47.

Carberry, E.J., Bharati, P., Levy, D.L. \& Chaudhury, A., (2017). Social Movements as Catalysts for Corporate Social Innovation: Environmental Activism and the Adoption of Green Information Systems. Business \& Society, pp.1-45. 
Carpenter, C. (2012). Conflict Minerals in the Congo: Blood Minerals and Africa's under-reported first World War, Working Paper: Suffolk University, April, 2. <http://web.mit.edu/ali_f/ MacData/afs.course.lockers/12/12.000/www/m2016/pdf/Congo.pdf.> (accessed 15 June, 2014).

Chen, J. \& Slotnick, S. A. (2015). Supply chain disclosure and ethical sourcing. International Journal of Production Economics, 161, 17-30.

Coetzee, C.M. \& van Staden, C.J., (2011), December. Disclosure responses to mining accidents: South African evidence. Accounting Forum, 35(4), 232-246.

Cooper, S. \& Owen, D. (2007). Corporate Social Reporting and Stakeholder Accountability: The Missing Link. Accounting, Organizations and Society, 32(7-8), 649-67.

Cho, C.H., Michelon, G., Patten, D.M., Roberts, R.W. (2015). The more things change...? Accounting, Auditing \& Accountability Journal, 28(1), 14-35.

Cho, C., Laine, M., Roberts, R. \& Rodrigue, M. (2015). Organized Hypocrisy, Organizational Façades, and Sustainability Reporting. Accounting Organizations and Society, 40(1), 78-94.

Cho, C. H., \& Patten, D. M. (2007). The role of environmental disclosures as tools of legitimacy: a research note. Accounting, Organizations and Society, 32(7/8), 639-647.

Clarkson, P. M., Li, Y., Richardson, G. D. \& Vasvari, F. P. (2008). Revisiting the relation between environmental performance and environmental disclosure: an empirical analysis. Accounting, Organizations and Society, 33(4), 303-327.

Criado-Jiménez, I., Fernández-Chulián, M., Larrinaga-González, C.\& Husillos-Carqués, F.J. (2008). Compliance with mandatory environmental reporting in financial statements: The case of Spain (2001-2003). Journal of Business Ethics, 79(3), 245-262.

Davis, G., Morrill, C., Rao, H. \& Soule, S. A. (2008). Introduction: Social Movements in Organizations and Markets. Administrative Science Quarterly, 53, 389-394.

Davies, J. C. (1962). Toward a Theory of Revolution. American Sociological Review, 27(1), 5-19.

De Bakker, F.G., Den Hond, F., King, B. \& Weber, K., (2013). Social movements, civil society and corporations: Taking stock and looking ahead. Organization Studies, 34(5-6), 573-593.

Deegan, C. (2014). Financial Accounting Theory, $\left(4^{\text {th }}\right.$ ed), McGraw Hill, Sydney.

Deegan, C. \& Islam, M. A., (2014). An exploration of NGO and media efforts to influence workplace practices and associated accountability within global supply chains. The British Accounting Review, 46(4), 397-415.

Deegan, C. (2002). The legitimizing Effect of Social and Environmental disclosures: A Theoretical Foundation. Accounting, Auditing \& Accountability Journal, 15(3), 282-311.

Deegan, C. \& Blomquist, C., (2006). Stakeholder Influence on Corporate Reporting: An Exploration of the Interaction between WWF- Australia and the Australian Minerals Industry. Accounting, Organizations and Society, 31, 343-72.

Deegan, C., Rankin, M. \& Tobin, J. (2002). An Examination of the Corporate Social and Environmental Disclosures BHP from 1983-1997: A Test of Legitimacy Theory. Accounting, Auditing \& Accountability Journal, 15(3), 312-43.

De Villiers, C. \& Van Staden, C. J. (2006). Can less environmental disclosure have a legitimising effect? Evidence from Africa. Accounting, Organizations and Society, 31 (8), 763-78

De Villiers, C. \& Van Staden, C. J. (2011). Where firms choose to disclose voluntary environmental information. Journal of Accounting and Public Policy, 30 (6), 504-525.

Delmas, M. A. \& Burbano, V. C. (2011). The drivers of greenwashing. California Management Review, 54(1), 64-87.

Dhaliwal, D. S., Radhakrishnan, S., Tsang, A. \& Yang, Y. G. (2012). Nonfinancial disclosure and analyst forecast accuracy: international evidence on corporate social responsibility disclosure. The Accounting Review, 87(3), 723-759.

Ernst \& Young (2012). Conflict minerals: What you need to know about the new disclosure and reporting requirements and how Ernst \& Young can help. Retrieved from Ernst \& Young website $<$ http://www.ey.com/Publication/vwLUAssets/Conflict_minerals/\$FILE/ Conflict Minerals US.pdf $>$. (accessed August 4, 2014>.

Frances, J. \& Garnsey, E. (1996). Supermarkets and Suppliers in the United Kingdom: System Integration, Information and Control. Accounting, Organizations and Society, 22 (6), 591-610.

Free, C. (2008). Walking the talk? Supply chain accounting and trust among UK supermarkets and suppliers. Accounting, Organizations and Society 33, 629-662. 
Frost, G. (2007). The Introduction of Mandatory Environmental Reporting Guidelines: Australian Evidence. ABACUS, 43 (2), 190-216.

Gamson, W.A., (1989). Reflections on the Strategy of Social Protest. Sociological Forum, 4(3), 455467.

Global Witness. (2011). Congo's mineral trade in the balance: Opportunities and obstacles to demilitarization. <http://www.globalwitness.org/sites/default/files/Congo\%27s\%20minerals\% 20trade\%20in\%20the\%20balance\%20low\%20res.pdf > (accessed January 20, 2015).

Gosman, M. L. \& Kohlbeck, M. J. (2009). Effects of the existence and identity of major customers on supplier profitability: Is Wal-Mart different? Journal of Management Accounting Research 21, 179-201.

Gray, B. (1996). Cross-sectoral partners: Collaborative alliances among business, government and communities, in Huxham, C. (Eds) Creating Collaborative Advantage (London: Sage).

Greenwood, R., Suddaby, R. \& Hinings, C. R. (2002). Theorizing change: The role of professional associations in the transformation of institutional fields. Academy of Management Journal, 45, $58-80$.

Griffin, P. A., Lont, D. H. \& Sun, Y. (2014). Supply chain sustainability: evidence on conflict minerals. Pacific Accounting Review, 26 (1/2), 28 - 53.

Grootaert, C. \& Patrinos, H. A. (eds) (1999). The Policy Analysis of Child Labor: A Comparative Study (London: St Martin's Press).

Gurr, T. (1970). Why Men Rebel. (Princeton: Princeton University Press).

Hackston, D. \& Milne, M. (1996). Some determinants of social and environmental disclosures in New Zealand companies. Accounting, Auditing \& Accountability Journal, 9(1), 77-108.

Haltsonen, I., Kourula, A. \& Salmi, A. (2007). Stakeholder Pressure and Socially Responsible Purchasing. Finance, Marketing and Production, Special Issue, 47-56.

Hochfelder, B. (2014). Preparing for the conflict Mineral Rule. Supply \& Demand Chain Executive, $14,8-12$.

Hogg, J. (2012). Conflict-free tags help revive Congo minerals trade. Reuters Nov 8 <http://www.reuters.com/article/2012/11/08/us-congo-democratic-miningidUSBRE8A70PG20121108> (accessed July 10, 2015).

Hooks, J. \& Van Staden, C. J. (2011). Evaluating environmental disclosures: the relationship between quality and extent measures. British Accounting Review, 43(3), 200-213.

ILO (2005). A global alliance against forced labour' Report of the Director -General, Global Report under the Follow-up to the ILO Declaration on Fundamental Principles and Rights at Work, 2005, Geneva, <http://www.ilo.org/wcmsp5/groups/public/@ed_norm/@ declaration/ documents/publication/wcms 081882.pdf> (accessed January 5, 2014).

Islam, M. \& Deegan, C. (2010). Media Pressures and Corporate Disclosure of Social Responsibility Performance: A Case Study of Two Global Clothing and Sports Retail Companies. Accounting and Business Research Journal, 40(2), 131-148.

Islam, M. \& Deegan, C., (2008). Motivations for an organization within a developing country to report social responsibility information: Evidence from Bangladesh. Accounting Auditing \& Accountability Journal, 21(6), 850-874.

Islam, M. A. \& McPhail, K. (2011). Regulating for corporate human rights abuses: The emergence of corporate reporting on the ILO's human rights standards within the global garment manufacturing and retail industry. Critical Perspective on Accounting, 22(8), 790-810.

Jenkins, J. C. (1983). Resource Mobilization Theory and the study of social movements. Annual Review of Sociology, 9, 527-53.

Kneip, V., 2013. Protest campaigns and corporations: Cooperative conflicts?. Journal of Business Ethics, 118(1), 189-202.

Kolk, A. \& Lenfant, F. (2012). Business-NGO collaboration in a conflict setting: Partnership activities in the Democratic Republic of Congo. Business \& Society, 51(3), 478-511.

Kolk, A. \& Van Tulder, R. (2002). Child labor and multinational conduct: a comparison of international business and stakeholder codes. Journal of Business Ethics, 36, 291-301.

Kettis, M. (2009). Children's Rights - a concern for investors Norges Bank Investment Management (NBIM), Norway <http://www.nbim.no/en/press-and-publications/featurearticles/2009/childrens-rights-a-concern-for-investors/> (accessed September, 2014). 
King, B.G. (2008). A political mediation model of corporate response to social movement activism. Administrative Science Quarterly, 53(3), 395-421.

King, B. G. \& Soule, S. A. (2007). Social Movements as Extra-institutional Entrepreneurs: The Effect of Protests on Stock Price Returns. Administrative Science Quarterly, 52(3), 413-442.

King, B.G., Bentele, K.G. \& Soule, S.A. (2007). Protest and policymaking: Explaining fluctuation in congressional attention to rights issues, 1960-1986. Social Forces, 86(1), 137-163.

Kostova, T. \& Zaheer, S. (1999). Organizational legitimacy under conditions of complexity: The case of the multinational enterprise. Academy of Management Review, 24, 64-81.

KPMG (2014). Conflict minerals and beyond, Part four: Lessons for an integrated compliance program, KPMG International.

Langfield-Smith, K. M. \& Smith, D. (2003). Management control systems and trust in outsourcing relationships. Management Accounting Research, 14, 281-307.

Leader, D. (2008). Business and Human Rights: Time to Hold Companies to Account. International Criminal Law Review, 8, 447-462.

Lezhnev, S. \& Hellmuth, A. (2012). Taking Conflict Out of Consumer Gadgets, Enough Project, <http://www.enoughproject.org/files/CorporateRankings2012.pdf> (accessed September, 2014).

Luders, J. (2006). The Economics of Movement Success: Business Responses to Civil Rights Mobilization 1. American Journal of Sociology, 111(4), 963-998.

Mansfield, E.D. \& Mutz, D.C. (2013). US versus them: mass attitudes toward offshore outsourcing. World Politics, 65, 571-608.

Martinez, D.E. \& Cooper, D.J., (2017). Assembling international development: Accountability and the disarticulation of a social movement. Accounting, Organizations and Society, in Press

Matthews, C. (2013). Conflict Mineral Reports Present Challenges for Auditors, WSJ Blogs $<$ http://blogs.wsj.com/corruption-currents/2013/01/29/conflict-mineral-reports-presentchallenges-for-auditors/> (accessed November, 2014).

Mandell, M.P. (1999). Community collaborations. Review of Policy Research, 16(1), 42-64.

Milne, M.J. and Patten, D.M., (2002). Securing organizational legitimacy: An experimental decision case examining the impact of environmental disclosures. Accounting, Auditing \& Accountability Journal, 15(3), 372-405.

Moodie, A. (2014). Amid legal uncertainty on conflict minerals, alternatives emerge: How can manufacturers - and consumers - fight the conflict minerals that are destabilising central Africa? < http://www.theguardian.com/sustainable-business/conflict-free-minerals-rulinglitigation-apple-intel> (accessed November, 2015).

Nelson, A. (2014). The Materiality of Morality: Conflict Minerals. Utah Law Review, 291-241.

Ness, K. \& Mirza, A. (1991). Corporate Social Disclosure: A Note on a Test of Agency Theory, British Accounting Review, 23, 211-17.

Neu, D., Rahaman, A. S. \& Everett, J. (2014). Accounting and sweatshops: enabling coordination and control in low- price apparel production chains. Contemporary Accounting Research, 31(2), $322-346$.

New, S. (2010). The transparent supply chain. Harvard Business Review, October, 76-82.

Oberschall, A. (1973). Social Conflict and Social Movements (Englewood Cliffs, N. J.: Prentice-Hall).

OECD (2013). OECD Due diligence guideline for responsible supply chains of minerals from conflict-affected and high-risk areas. OECD Publishing, 2nd Edition.

OECD (2011). OECD Due diligence guidance for responsible supply chains of minerals from conflict-affected and high-risk areas, OECD Publishing, May 2011.

Oetzel, J. \& Doh, J. P. (2009). MNEs and development: A review and reconceptualization. Journal of World Business, 44(2), 108-120.

OneWorld US (2006). Investors Target Hershey Over Child Labor on Cocoa Farms < http://oneworldus.civiblog.org/blog/_archives/2006/4/12/1881920.html.> (accessed 11 October, 2014).

O’Dwyer, B. \& Unerman, J. (2016). Fostering rigour in accounting for social sustainability. Accounting, Organizations and Society, 49, 32-40. 
O'Dwyer, B. \& Unerman, J., (2008). The paradox of greater NGO accountability: A case study of Amnesty Ireland. Accounting, Organizations and Society, 33(7), 801-824.

O'Sullivan, N. \& O'Dwyer, B. (2015). The structuration of issue-based fields: social accountability, social movements and the Equator Principles issue-based field. Accounting, Organizations and Society, 43, 33-55.

Psacharopoulos, G. (1997). Child labor versus educational attainment: some evidence from Latin America. Journal of Population Economics, 10(4), 377-386.

Patten, D. M. (2002). The relation between environmental performance and environmental disclosure: a research note. Accounting, Organizations and Society, 27, 763-773.

Patten, D.M., (1992). Intra-industry environmental disclosures in response to the Alaskan oil spill: a note on legitimacy theory. Accounting, organizations and Society, 17(5), 471-475.

Preston, A.M., Cooper, D.J. and Coombs, R.W. (1992). Fabricating budgets: a study of the production of management budgeting in the National Health Service. Accounting, Organizations and Society, 17(6), 561-593.

Raise Hope For Congo (2010), About the Campaign. Enough Campaign. http://www.raisehopefor congo.org/content/about/about-the-campaign (accessed November 7, 2014).

Reese, A. K. (2010). Blood Minerals' in the Supply Chain. Supply and Demand Executive, August, 8.

Reinecke, J. \& Ansari, S. (2016). Taming Wicked Problems: The Role of Framing in the Construction of Corporate Social Responsibility. Journal of Management Studies, 53(3), 299-329.

Rondinelli, D.A. \& London, T. (2003). How corporations and environmental groups cooperate: Assessing cross-sector alliances and collaborations. The Academy of Management Executive, 17(1), 61-76.

Roberts, R.W. (1992). Determinants of corporate social responsibility disclosure: an application of stakeholder theory. Accounting, Organizations and Society 17(6), 595-612.

Ruggie. J. (2011). Report of the Special Representative of the Secretary General on the issue of human rights and transnational corporations and other business enterprises, United Nations General Assembly (21 March 2011), UN Doc. A/HRC/17/31. p. 16.

Seal, W., Berry, A. \& Cullen, J. (2004). Disembedding the supply chain: Institutionalized reflexivity and inter-firm accounting. Accounting, Organizations and Society, 29(1), 73-92.

Silva-Gao, L. (2012). The disclosure of environmental capital expenditures: evidence from the electric utility sector in the USA. Corporate Social Responsibility and Environmental Management, 19 (4), 240-252.

SEC. (2012). Dodd-Frank Wall Street Reform and Consumer Protection Act, H.R. 4173, http://www.sec.gov/about/laws/wallstreetreform-cpa.pdf, pp. 838-843; SEC, "Final Rule."

Share (2011). Canadian Investors Addressing Child Labour in Cotton Supply-Chains, Shareholder Association for research and education <http://www.share.ca/news/canadian-investorsaddressing-child-labour-in-cotton-supply-chains/>(accessed October, 2013).

Shelton R. K, \& Wachter, K. (2005). Effects of global sourcing on textiles and apparel. Journal of Fashion Marketing and Management, 9(3), 318-329.

Soule S.A. (2012). Social Movements and Markets, Industries, and Firms. Organization Studies $33(12), 1715-1733$.

Soule, S. A. (2009). Contentious and Private Politics and Corporate Social Responsibility. (Cambridge, UK: Cambridge University Press).

Soule, S. A. \& King, B. (2006). The Impact of Social Movements at Stages of the Policy Process: The Equal Rights Amendment, 1972-1982., American Journal of Sociology, 111(6), 1871-1909.

Soule, S.A., McAdam, D., McCarthy, J. \& Su, Y. (1999). Protest Events: Cause or Consequence of State Action? The U.S. Women's Movement and Federal Congressional Activities, 1956-1979. Mobilization 4(2), 239-256.

Spar, D. (1998). The Spotlight and the Bottom line: How Multinationals Export Human rights, Foreign Affairs, March/April, pp. 7-12.

Spence, L. \& Rinaldi, L. (2014). Governmentality in accounting and accountability: a case study of embedding sustainability in a supply chain. Accounting, Organizations and Society, 39(6), 433452

Taylor, C. R. (2014). Drowning in Disclosure: The Overburdening of the Securities \& Exchange Commission. Virginia Law \& Business Review, 85. 
Tilly, C. (1978). From Mobilization to Revolution, Comparative Perspectives on Social Movements, pp.1-20. (Reading, M.A: Addison-Wesley).

Tilt, C. (1994). The Influence of External Pressure Groups on Corporate Social Disclosure. Accounting, Auditing \& Accountability Journal, 7(4), 47-72.

Toch, H. (1965). The Social Psychology of Social Movements. Indianapolis: Bobbs-Merrill.

United States Geological Survey (USGS). (2010), Report. Available at < www.usgs.org> (accessed 15 May 2014).

Unerman, J. \& Chapman, C. (2014). Academic contributions to enhancing accounting for sustainable development. Accounting, Organizations and Society, 39(6), 385-394.

UN (2008). Human Trafficking: An Overview, UN.GIFT (United Nations Global Initiatives to fight human Trafficking, United Nations Office on Drugs and Crime, Vienna, United Nations.

UN Global Compact, (2011). Dilemma: Accusations of forced child labour cause serious concern among investors. <http://human-rights.unglobalcompact.org/case_studies/forced-labour/forced _labour/combating_forced_child_labour_in_uzbekistan.html> (Accessed 15 May, 2015).

Van Staden, C.J. \& Hooks, J. (2007). A comprehensive comparison of corporate environmental reporting and responsiveness. British Accounting Review, 39(3), 197-210.

Verbruggen D., Francq E. \& Cuvelier J. (2011). Guide to current mining reform initiatives in eastern DRC, IPIS.

Wallace, R. S. O. \& Naser, K. (1996). Firm-specific determinants of the comprehensiveness of mandatory disclosure in the corporate annual reports of firms listed on the stock exchange of Hong Kong. Journal of Accounting and Public policy, 14(4), 311-368.

Wah, L. (1998). Treading the Sacred Ground. Management Review, 87(7), 18-22.

Wang, D. J., \& Soule, S. A. (2012). Social Movement Organizational Collaboration: Networks of Learning and the Diffusion of Protest Tactics, 1960-19951. American Journal of Sociology, 117(6), 1674-1722.

Whiteman, G. \& Cooper, W.H. (2016) Decoupling rape. Academy of Management Discoveries, 2(2), $115-154$.

World Bank (2009). Human Trafficking: A Brief Overview, Social Development Notes, No. 122 / December <http://siteresources.worldbank.org/EXTSOCIALDEVELOPMENT/Resources/ 244362-1239390842422/6012763-1239905793229/Human_Trafficking.pdf> (accessed 8 July, 2014).

Wood, D. J. \& Gray, B. (1991). Toward a Comprehensive Theory of Collaboration. Journal of Applied Behavioral Science, 27(2), 139-162. 
Table 1: Conflict mineral disclosure index

\begin{tabular}{|c|c|c|c|c|}
\hline & Themes & Scale & CS & Application of scale \\
\hline A & $\begin{array}{l}\text { Management commitment } \\
\text { to reduce the use of conflict } \\
\text { minerals in the supply chain }\end{array}$ & $0-2$ & 2 & $\begin{array}{l}\text { No disclosure of commitment or plan, } 0 \\
\text { Briefly mentioned (just produced a statement of commitment), } 1 \\
\text { Detailed coverage of commitment including future goals and } \\
\text { strategies, } 2\end{array}$ \\
\hline B & $\begin{array}{l}\text { Determine if the minerals } \\
\text { originate in the DRC or its } \\
\text { neighbouring countries }\end{array}$ & $0-2$ & 4 & $\begin{array}{l}\text { If source or origin of minerals is 'undeterminable', } 0 \\
\text { If source or origin of minerals is 'party determinable' and 'party } \\
\text { undeterminable', } 1 \\
\text { If all sources are determinable, } 2 \text {. }\end{array}$ \\
\hline $\mathbf{C}$ & $\begin{array}{l}\text { Exercise due diligence based } \\
\text { on an approved framework } \\
\text { (such as the OECD due } \\
\text { diligence guidance) to } \\
\text { determine the origin of the } \\
\text { minerals }\end{array}$ & $0-2$ & 6 & $\begin{array}{l}\text { If no due diligence framework is reported, } 0 \\
\text { If there is reference to a due diligence framework (for example, the } \\
\text { OECD Due Diligence Guidance, see } \\
\text { www.OECD.daf/investment/mining) (minimal description), } 1 \\
\text { If details of the process is provided and checklist/benchmark against } \\
\text { best practice guidance such as the OECD due diligence guidance, } 2\end{array}$ \\
\hline D & $\begin{array}{l}\text { Evidence/examples of } \\
\text { communications with } \\
\text { suppliers regarding due } \\
\text { diligence expectations }\end{array}$ & $0-2$ & 8 & $\begin{array}{l}\text { No example, } 0 \\
\text { One example, } 1 \\
\text { More than one examples, } 2\end{array}$ \\
\hline 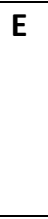 & $\begin{array}{l}\text { Evidence of any risk } \\
\text { management and associated } \\
\text { performance including a } \\
\text { description of the time } \\
\text { frame for improvement }\end{array}$ & $0-2$ & 10 & $\begin{array}{l}\text { No discussion of risk management, } 0 \\
\text { Reference to risk management and associated strategy, } 1 \\
\text { Details of how risk has been (is) managed and related improvement, } 2\end{array}$ \\
\hline $\mathbf{F}$ & $\begin{array}{l}\text { Amount of money (cost } \\
\text { information) spent in an } \\
\text { attempt to eliminate the use } \\
\text { of conflict minerals in the } \\
\text { supply chain }\end{array}$ & $0-2$ & 12 & $\begin{array}{l}\text { No disclosure of cost associated with the use and/or elimination of } \\
\text { conflict minerals, } 0 \\
\text { Disclosure of current aggregate amount spent to reduce the use of } \\
\text { conflict minerals, } 1 \\
\text { Disclosure of details of current period expenditure by segments, } \\
\text { country, or major suppliers, and/or, disclosure of expenditure detail } \\
\text { of past and present with estimated cost for the future period through } \\
\text { comparative statements, } 2\end{array}$ \\
\hline $\mathbf{G}$ & $\begin{array}{l}\text { Number of suppliers } \\
\text { involved with conflict } \\
\text { minerals and reduction of } \\
\text { these }\end{array}$ & $0-2$ & 14 & $\begin{array}{l}\text { No disclosure of number of suppliers with conflict minerals, } 0 \\
\text { Reference total number of suppliers with conflict minerals, } 1 \\
\text { Details of improvement (i.e., reduction) in the number of suppliers } \\
\text { with conflict minerals compared to previous year, and/or, year-wise } \\
\text { comparative data in the reduction of suppliers with conflict minerals } \\
\text { with future targets, } 2\end{array}$ \\
\hline $\mathbf{H}$ & $\begin{array}{l}\text { Evidence of regular } \\
\text { monitoring of supply chains } \\
\text { to minimise the use of } \\
\text { conflict minerals }\end{array}$ & $0-2$ & 16 & $\begin{array}{l}\text { No mention of monitoring of supply chains, } 0 \\
\text { Statement of regular monitoring without improvement (of } \\
\text { performance) data, } 1 \\
\text { Details of regular monitoring with improvement data and statistics, } 2\end{array}$ \\
\hline$I$ & $\begin{array}{l}\text { Conducting conflict mineral } \\
\text { audits and associated } \\
\text { reporting }\end{array}$ & $0-2$ & 18 & $\begin{array}{l}\text { If there is no audit, } 0 \\
\text { If the conflict mineral report is audited only by an internal auditor, } 1 \\
\text { If the conflict mineral report is audited by a third party, } 2\end{array}$ \\
\hline
\end{tabular}

Note: CS = cumulative score. 
Table 2: Descriptive statistics for the elements of the disclosures on conflict minerals

\begin{tabular}{|c|c|c|c|c|c|c|c|}
\hline Item & Item description & Minimum & Maximum & Mean & $\begin{array}{l}\text { Standard } \\
\text { Deviation }\end{array}$ & $\begin{array}{l}\text { Maximum } \\
\text { possible } \\
\text { score }\end{array}$ & $\begin{array}{l}\text { Average } \\
\text { disclosure } \\
\text { score }\end{array}$ \\
\hline A & $\begin{array}{l}\text { Management commitment to reduce the use } \\
\text { of conflict minerals in the supply chain }\end{array}$ & 0.00 & 2.00 & 1.230 & 0.501 & 2.00 & $61.50 \%$ \\
\hline B & $\begin{array}{l}\text { Determine if the minerals originate in the } \\
\text { DRC or its neighbouring countries }\end{array}$ & 0.00 & 2.00 & 0.261 & 0.457 & 2.00 & $13.05 \%$ \\
\hline C & $\begin{array}{l}\text { Exercise due diligence based on an approved } \\
\text { framework (such as OECD due diligence } \\
\text { guidance) to determine the origin of the } \\
\text { minerals }\end{array}$ & 0.00 & 2.00 & 1.108 & 0.561 & 2.00 & $55.40 \%$ \\
\hline D & $\begin{array}{l}\text { Evidence/examples of communications with } \\
\text { suppliers regarding due diligence } \\
\text { expectations }\end{array}$ & 0.00 & 2.00 & 0.254 & 0.454 & 2.00 & $12.70 \%$ \\
\hline$E$ & $\begin{array}{l}\text { Evidence of any risk management and } \\
\text { associated performance including a } \\
\text { description of the time frame for } \\
\text { improvement }\end{array}$ & 0.00 & 2.00 & 0.913 & 0.391 & 2.00 & $45.65 \%$ \\
\hline $\mathbf{F}$ & $\begin{array}{l}\text { Amount of money (cost information) spent in } \\
\text { an attempt to eliminate conflict minerals in } \\
\text { the supply chain }\end{array}$ & 0.00 & 1.00 & 0.029 & 0.168 & 2.00 & $1.45 \%$ \\
\hline G & $\begin{array}{l}\text { Number of suppliers involved with conflict } \\
\text { minerals and reduction of these }\end{array}$ & 0.00 & 2.00 & 0.381 & 0.664 & 2.00 & $19.05 \%$ \\
\hline $\mathbf{H}$ & $\begin{array}{l}\text { Evidence of regular monitoring of supply } \\
\text { chains to minimise the use of conflict } \\
\text { minerals }\end{array}$ & 0.00 & 2.00 & 0.950 & 0.387 & 2.00 & $47.50 \%$ \\
\hline \multirow[t]{2}{*}{ I } & $\begin{array}{l}\text { Conducting conflict mineral audits and } \\
\text { associated reporting }\end{array}$ & 0.00 & 2.00 & 0.619 & 0.896 & 2.00 & $30.95 \%$ \\
\hline & Total Disclosure Score & 1.00 & 12.00 & 5.727 & 2.461 & 18.00 & $31.82 \%$ \\
\hline
\end{tabular}

Note: This table shows the actual scores allocated to each category and in total. The last column show a percentage score based on the actual score and the maximum possible score for each category and in total. 
Table 3: Summary of Variables

\begin{tabular}{|c|c|c|c|}
\hline Variable & Designation & Source & Calculation \\
\hline $\begin{array}{l}\text { Comprehensiveness } \\
\text { of disclosures }\end{array}$ & Disclosure & $\begin{array}{l}\text { Hand- collected from } \\
\text { conflict mineral reports } \\
\text { filed with the SEC }\end{array}$ & $\begin{array}{l}\text { Disclosure score determined using a } \\
\text { disclosure index (see Table 1) being a } \\
\text { percentage calculated using the actual } \\
\text { score over the potential total score. }\end{array}$ \\
\hline $\begin{array}{l}\text { Collaboration with } \\
\text { Social movement } \\
\text { NGOs }\end{array}$ & NGOCollab & $\begin{array}{l}\text { Hand-collected from the } \\
\text { company reports, } \\
\text { websites, conflict mineral } \\
\text { reports and collaborator } \\
\text { NGO online resources }\end{array}$ & $\begin{array}{l}\text { Reflects the number of collaborations } \\
\text { a company had during the year with a } \\
\text { social movement NGO (with regards to } \\
\text { conflict minerals). }\end{array}$ \\
\hline Activist protest & Protest & $\begin{array}{l}\text { Media articles from the } \\
\text { Dow Jones Factiva } \\
\text { database and the Business } \\
\text { and Human Rights } \\
\text { Resource Centre (BHRRC) }\end{array}$ & $\begin{array}{l}\text { The number of protest events based } \\
\text { on a keyword search using 'protest', } \\
\text { 'boycott', 'demonstration', 'campaign', } \\
\text { 'NGO', 'activist', 'human rights', } \\
\text { 'conflict minerals', and 'supply chains' } \\
\text { as keywords }\end{array}$ \\
\hline CSR Performance & CSRPerf & Bloomberg Data & $\begin{array}{l}\text { CSR performance using the ESG } \\
\text { measure from Bloomberg. The ESG } \\
\text { score ranges from } 0 \text { to } 100 \text { and is } \\
\text { designed to capture actual CSR } \\
\text { performance, rather than just policies } \\
\text { and intentions }\end{array}$ \\
\hline Size measure & SIZE & Bloomberg Data & Natural log of total assets \\
\hline Return on Assets & $R O A$ & Bloomberg Data & $\begin{array}{l}\text { Net profit before tax over average } \\
\text { total assets }\end{array}$ \\
\hline Leverage & LEV & Bloomberg Data & $\begin{array}{l}\text { Financial leverage being average total } \\
\text { assets over average total common } \\
\text { equity }\end{array}$ \\
\hline Tobin's Q & TOBIN Q & Bloomberg Data & $\begin{array}{l}\text { (Market Capitalization + Total } \\
\text { Liabilities + Preferred Equity + Minority } \\
\text { Interest) / Total Assets }\end{array}$ \\
\hline Volatility measure & VOLAT & Bloomberg Data & $\begin{array}{l}\text { Share price volatility being the } \\
\text { standard deviation of day to day } \\
\text { logarithmic historical price changes. } \\
\text { The } 360 \text {-day price volatility equals the } \\
\text { annualized standard deviation of the } \\
\text { relative price change for the } 360 \text { most } \\
\text { recent trading days' closing price, } \\
\text { expressed as a percentage. }\end{array}$ \\
\hline Industry classification & $\begin{array}{l}\text { Info Tech, } \\
\text { Industrials, } \\
\text { Energy, } \\
\text { Healthcare, } \\
\text { Cons Discr }\end{array}$ & $\begin{array}{l}\text { Bloomberg Data. All } \\
\text { industry classifications are } \\
\text { based on the GICS } \\
\text { classifications. }\end{array}$ & $\begin{array}{l}\text { Info Tech is the Information } \\
\text { Technology and Tele-communication } \\
\text { industry. } \\
\text { Industrials is the Industrial industry. } \\
\text { Healthcare is the Healthcare industry. } \\
\text { Cons Discr is the consumer discretion } \\
\text { industry. }\end{array}$ \\
\hline Country variable & $\begin{array}{l}\text { USA, Europe, } \\
\text { Japan, Rest of } \\
\text { the world }\end{array}$ & Forbes Global 2000 & $\begin{array}{l}\text { Shows whether a company is } \\
\text { registered in the USA, Europe, Japan or } \\
\text { the rest of the world (countries with } \\
\text { less than five companies). }\end{array}$ \\
\hline
\end{tabular}


Table 4: Descriptive statistics

\begin{tabular}{lllllll}
\hline Variable & $\mathrm{N}$ & Mean & Median & Minimum & Maximum & Std dev \\
\hline Disclosure & 139 & $31.82 \%$ & $25.00 \%$ & $5.55 \%$ & $66.67 \%$ & $12.30 \%$ \\
NGOCollab & 139 & 0.75 & 0.00 & 0 & 3 & 0.86 \\
Protest & 139 & 1.31 & 0.00 & 0 & 24 & 2.88 \\
CSRPerf & 133 & 35.99 & 35.95 & 5.37 & 83.06 & 17.14 \\
SIZE & 139 & $50,497,294$ & $15,930,970$ & $1,685,490$ & $656,560,000$ & $89,992,818$ \\
ROA & 139 & 8.08 & 6.82 & -9.34 & 67.31 & 8.50 \\
LEV & 139 & 3.06 & 2.14 & 1.13 & 47.13 & 4.29 \\
TOBIN Q & 139 & 1.89 & 1.69 & 0.85 & 6.35 & 0.90 \\
VOLAT & 139 & 25.54 & 24.08 & 13.78 & 56.08 & 8.65 \\
\hline
\end{tabular}

Notes: Disclosure is the disclosure score being a percentage calculated using the actual score over the potential total score. NGOCollab is the extent of collaboration with NGOs. Protest is the number of protest events based on Factiva and BHRRC. CSRPerf is the CSR performance using the ESG measure from Bloomberg. SIZE is total assets in US\$. ROA is return on assets. $L E V$ is financial leverage. TOBIN $Q$ is Tobin's Q. VOLAT is share price volatility. Missing data caused $\mathrm{N}$ for CSRPerf to be less than 139. In this table SIZE is expressed in US\$000, but in all other tables and analyses the natural log is used. 
Table 5: Correlations

\begin{tabular}{|c|c|c|c|c|c|c|c|c|c|c|c|c|}
\hline & Disclosure & NGOCollab & Protest & CollabxProt & CSRPerf & SIZE & $R O A$ & $L E V$ & TOBIN Q & VOLAT & Info Tech & Industrials \\
\hline Disclosure & - & $0.569 * *$ & $0.444^{* *}$ & $0.564 * *$ & 0.139 & 0.023 & 0.001 & -0.089 & 0.088 & 0.199* & $0.239 * *$ & 0.026 \\
\hline NGOCollab & $0.573^{* *}$ & - & $0.299 * *$ & $0.640 * *$ & 0.132 & 0.027 & -0.076 & 0.015 & 0.038 & $0.238 * *$ & $0.259 * *$ & 0.022 \\
\hline Protest & $0.387 * *$ & $0.281 * *$ & - & $0.717 * *$ & $0.487 * *$ & $0.493 * *$ & -0.161 & 0.091 & $-0.215^{*}$ & 0.096 & $0.220 * *$ & 0.031 \\
\hline CollabxProt & $0.425 * *$ & $0.434^{* *}$ & $0.876 * *$ & - & $0.330 * *$ & $0.275^{* *}$ & -0.041 & 0.039 & -0.040 & 0.054 & $0.211^{*}$ & 0.039 \\
\hline CSRPerf & 0.168 & 0.147 & $0.357^{* *}$ & $0.233^{* *}$ & - & $0.648 * *$ & $-0.238 * *$ & 0.129 & $-0.310 * *$ & -0.088 & 0.103 & 0.023 \\
\hline SIZE & 0.041 & 0.070 & $0.416 * *$ & $0.286 * *$ & $0.604 * *$ & - & $-0.285^{* *}$ & 0.166 & $-0.368 * *$ & $-0.276 * *$ & -0.105 & 0.132 \\
\hline$R O A$ & 0.017 & -0.074 & -0.028 & 0.013 & $-0.291 * *$ & $-0.318 * *$ & - & $-0.435^{* *}$ & $0.695^{* *}$ & $-0.249 * *$ & -0.025 & -0.004 \\
\hline LEV & -0.067 & 0.072 & -0.012 & -0.002 & 0.071 & 0.108 & -0.103 & - & $-0.271 * *$ & 0.026 & -0.150 & $0.220 * *$ \\
\hline$T O B I N Q$ & 0.051 & 0.028 & -0.096 & -0.018 & $-0.305^{* *}$ & $-0.419 * *$ & $0.395^{* *}$ & -0.075 & - & $-0.287^{*}$ & -0.046 & 0.086 \\
\hline VOLAT & $0.210 *$ & $0.247 * *$ & $0.181^{*}$ & $0.175^{*}$ & -0.002 & $-0.226 * *$ & -0.065 & 0.049 & $-0.238 * *$ & - & $0.281 * *$ & $-0.327^{* *}$ \\
\hline Info Tech & $0.225^{* *}$ & $0.243 * *$ & $0.217^{*}$ & $0.171 *$ & 0.101 & -0.116 & 0.061 & 0.037 & -0.017 & $0.249 * *$ & - & $-0.430 * *$ \\
\hline Industrials & 0.058 & 0.017 & -0.021 & -0.006 & 0.013 & 0.115 & -0.057 & 0.046 & -0.008 & $-0.279 * *$ & $-0.430 * *$ & - \\
\hline Energy & $-0.254^{* *}$ & $-0.292 * *$ & -0.109 & -0.107 & 0.096 & $0.213^{*}$ & -0.041 & -0.070 & -0.146 & -0.110 & $-0.360 * *$ & -0.166 \\
\hline Healthcare & -0.107 & $-0.204^{*}$ & -0.133 & -0.092 & -0.127 & -0.147 & 0.012 & -0.081 & 0.094 & $-0.182^{*}$ & $-0.348 * *$ & -0.161 \\
\hline Cons Discr & -0.052 & 0.103 & -0.070 & -0.058 & -0.146 & -0.025 & 0.002 & 0.041 & 0.094 & $0.229 * *$ & $-0.348 * *$ & -0.161 \\
\hline USA & 0.101 & -0.036 & -0.088 & -0.012 & $-0.288 * *$ & $-0.206^{*}$ & 0.081 & -0.091 & $0.246 * *$ & -0.161 & -0.117 & 0.053 \\
\hline Europe & -0.001 & 0.027 & 0.087 & 0.053 & $0.187^{*}$ & $0.182 *$ & -0.009 & 0.158 & -0.092 & -0.007 & 0.036 & -0.007 \\
\hline Japan & -0.020 & 0.061 & -0.011 & -0.031 & 0.089 & $0.196 *$ & -0.137 & -0.009 & $-0.184^{*}$ & 0.140 & -0.063 & 0.001 \\
\hline $\begin{array}{l}\text { Rest of the } \\
\text { world }\end{array}$ & -0.146 & -0.020 & 0.034 & -0.029 & 0.155 & -0.048 & -0.021 & -0.056 & -0.144 & $0.169 *$ & $0.185^{*}$ & -0.077 \\
\hline
\end{tabular}


Table 5 - Correlations (continued)

\begin{tabular}{|c|c|c|c|c|c|c|c|}
\hline & Energy & Healthcare & Cons Discr & USA & Europe & Japan & Rest \\
\hline Disclosure & $-0.262 * *$ & -0.093 & -0.042 & 0.113 & -0.016 & -0.019 & -0.146 \\
\hline NGOCollab & $-0.302 * *$ & $-0.208 *$ & 0.087 & -0.029 & 0.010 & 0.070 & -0.015 \\
\hline Protest & -0.165 & $-0.174 *$ & -0.037 & -0.166 & 0.131 & -0.011 & 0.100 \\
\hline CollabxProt & $-0.222 * *$ & -0.130 & -0.018 & 0.036 & -0.014 & -0.038 & -0.013 \\
\hline CSRPerf & 0.080 & -0.119 & -0.153 & $-0.295 * *$ & $0.208^{*}$ & 0.100 & 0.128 \\
\hline SIZE & $0.192 *$ & -0.138 & -0.048 & $-0.210^{*}$ & $0.196^{*}$ & $0.176^{*}$ & -0.046 \\
\hline$R O A$ & 0.010 & 0.089 & -0.054 & $0.215^{*}$ & -0.112 & $-0.243 * *$ & -0.027 \\
\hline LEV & -0.093 & -0.092 & 0.166 & -0.045 & 0.094 & 0.014 & -0.062 \\
\hline TOBIN Q & -0.147 & $0.187^{*}$ & -0.065 & $0.285^{* *}$ & -0.055 & $-0.270 * *$ & $-0.195^{*}$ \\
\hline VOLAT & -0.099 & $-0.210 *$ & $0.252 * *$ & $-0.170 *$ & -0.050 & 0.161 & $0.225^{* *}$ \\
\hline Info Tech & $-0.360 * *$ & $-0.348 * *$ & $-0.348 * *$ & -0.117 & 0.036 & -0.063 & $0.185^{*}$ \\
\hline Industrials & -0.166 & -0.161 & -0.161 & 0.053 & -0.007 & 0.001 & -0.077 \\
\hline Energy & - & -0.135 & -0.135 & 0.065 & 0.054 & -0.079 & -0.120 \\
\hline Healthcare & -0.135 & - & -0.130 & 0.149 & -0.052 & -0.077 & -0.116 \\
\hline Cons Discr & -0.135 & -0.130 & - & -0.094 & -0.052 & $0.256 * *$ & 0.039 \\
\hline USA & 0.065 & 0.149 & -0.094 & - & $-0.688^{* *}$ & $-0.312^{* *}$ & $-0.472 * *$ \\
\hline Europe & 0.054 & -0.052 & -0.052 & $-0.688 * *$ & - & -0.099 & -0.150 \\
\hline Japan & -0.079 & -0.077 & $0.256 * *$ & $-0.312 * *$ & -0.099 & - & -0.068 \\
\hline Rest of the world & -0.120 & -0.116 & 0.039 & $-0.472 * *$ & -0.150 & -0.068 & - \\
\hline
\end{tabular}

Notes: All variables are explained in Table 3.

Significance $*$ at the $5 \%$ and $* *$ at the $1 \%$ levels respectively. The Pearson correlation is below the diagonal. Spearman's Rho is above the diagonal. 


\section{Table 6 Means comparisons}

\begin{tabular}{|c|c|c|c|}
\hline \multicolumn{4}{|c|}{ Panel A NGO Collaboration } \\
\hline & $\begin{array}{l}\text { Collaboration } \\
\text { Mean } \\
(N=65)\end{array}$ & $\begin{array}{l}\text { No Collaboration } \\
\text { Mean } \\
(\mathrm{N}=74)\end{array}$ & t-stat \\
\hline Disclosure & 36.154 & 22.027 & $8.225^{* * *}$ \\
\hline Protest & 1.95 & 0.74 & $2.519 * * *$ \\
\hline CSR Performance & 38.020 & 34.163 & 1.229 \\
\hline \multicolumn{4}{|c|}{ Panel B Disclosure Scores } \\
\hline & $\begin{array}{c}\text { Above average } \\
\text { Mean } \\
(N=69)\end{array}$ & $\begin{array}{c}\text { Below average } \\
\text { Mean } \\
(N=70)\end{array}$ & t-stat \\
\hline Collaboration & 0.72 & 0.21 & $6.961 * * *$ \\
\hline Protest & 2.07 & 0.56 & $3.202 * * *$ \\
\hline CSR Performance & 38.075 & 33.996 & 1.374 \\
\hline \multicolumn{4}{|c|}{ Panel C US Companies } \\
\hline & $\begin{array}{c}\text { US } \\
\text { Mean } \\
(N=95)\end{array}$ & $\begin{array}{l}\text { Non US } \\
\text { Mean } \\
(N=44)\end{array}$ & t-stat \\
\hline Disclosure & 29.474 & 26.818 & 1.163 \\
\hline Collaboration & 0.46 & 0.48 & -0.154 \\
\hline Protest & 1.14 & 1.68 & -1.037 \\
\hline CSR Performance & 32.711 & 43.349 & $-3.409 * * *$ \\
\hline
\end{tabular}

Note: $* * *$ represent significance at the $1 \%$ level, two-tailed. 
Table 7: Results of the 3SLS regression

\begin{tabular}{lrl}
\hline & Coefficient & p-value \\
\hline NGOCollab (+) & $\mathbf{1 9 . 4 3 3}$ & $\mathbf{0 . 0 0 \boldsymbol { * } ^ { * * }}$ \\
Protest (+) & $\mathbf{9 . 2 4 4}$ & $\mathbf{0 . 0 1 5 ^ { * * }}$ \\
NGOCollabXProtest & $\mathbf{0 . 7 6 9}$ & $\mathbf{0 . 0 1 7 ^ { * * }}$ \\
CSRPerf & 0.022 & 0.753 \\
SIZE & -0.659 & 0.595 \\
ROA & 0.296 & $0.035^{* *}$ \\
LEV & -0.358 & $0.087^{*}$ \\
TOBIN Q & -1.361 & 0.320 \\
VOLAT & -0.123 & 0.431 \\
Industrials & 2.544 & 0.371 \\
Energy & 6.400 & 0.108 \\
Healthcare & 6.358 & $0.067^{*}$ \\
Cons Discr & -5.241 & 0.103 \\
Europe & -1.973 & 0.420 \\
Japan & -1.610 & 0.735 \\
Rest & -7.285 & $0.050^{* *}$ \\
Constant & 22.916 & 0.114 \\
\hline N & 131 & \\
Adj. $R^{2}$ & 0.3487 & \\
\hline
\end{tabular}

Notes: All variables have been defined in Tables 3 and 4 .

$*, * *$ and $* * *$ represent significance levels at the $10 \%, 5 \%$, and $1 \%$ levels respectively, all two-tailed. 


\section{Appendix 1: Description of major NGO collaborators}

EICC (Electronic Industry Citizenship Coalition), founded in 2004 is a Washington based non-profit alliance of electronics, retail, auto and toy companies committed to protecting the rights of workers and communities worldwide affected by the global electronics supply chain. While the activities of the EICC have gone beyond compliance, standard setting, training and capacity building, accountability and transparency remain a core EICC activity. In the collaboration continuum (Austin, 2000), EICC appears an intensive and engaged alliance to create change in supply chain transparency. GeSI (Global e-sustainability Initiative) is a Brussels based alliance and the leading source for impartial and credible information on emerging issues in the area of Information and Communications Technology (ICT) and the development of human rights guidance for the ICT sector. It is engaged in efforts to promote human rights and ensure that ICT products do not contain "conflict minerals". In the collaboration continuum (Austin, 2000), GeSI's collaboration is at policy and thought level (standard setting level) and less intensive and less engaged than EICC's collaboration in achieving transparency and accountability in the global supply chains.

CFSI (Conflict- Free Sourcing Initiatives), a Washington based global alliance founded in 2008, have grown into one of the most utilized and respected resources for companies from a range of industries addressing conflict mineral issues in their supply chains. Over 350 companies collaborate with the CFSI, contributing to a range of activities and resources i.e., the 'Conflict-Free Smelter Program', 'Field Visits', 'Conflict Minerals Reporting Template', 'Reasonable Country of Origin Inquiry data', Monitoring', 'Check Compliances' and a range of guidance documents on conflict mineral sourcing. Through its Conflict-Free Smelter Program, CFSI offers companies and their suppliers conflict mineral disclosure guidance and independent, third-party, monitoring that determines which smelters and refiners can be validated as "conflict-free". CFSI engages with a variety of other NGOs, responsible investor groups, governments and multilateral institutions to discuss emerging issues, best practices and work on addressing shared challenges. In terms of the collaboration notion, CFSI appears to be a more engaged, more specific, more intensive and more interactive collaborator (Rondinelli and London, 2003; Mandell, 1999; Austin, 2000) than any other NGO collaborator considered in this study.

AIAG (Automotive Industry Action Group) is a US based not-for-profit association founded in 1982, to collaborate with a diverse group of stakeholders to streamline industry processes via global standards development and harmonized business practices, including responsible supply chain practices. In collaboration with corporations, it takes progressive steps to demonstrate its commitment to the elimination of conflict minerals, and develop resources to assist with the conflict mineral compliance process. Compared to other NGO collaborators considered in this study, AIAG provides general, less intensive and less engaged collaborations with companies in an attempt to eliminate human rights concerns in the conflict mineral zones. 